\title{
Valorization Potential of a Novel Bacterial Strain, Bacillus altitudinis RSP75, towards Lignocellulose Bioconversion: An Assessment of Symbiotic Bacteria from the Stored Grain Pest, Tribolium castaneum
}

\author{
Mudasir A. Dar ${ }^{1,2}$, Neeraja P. Dhole ${ }^{2,+}$, Rongrong Xie ${ }^{1}$, Kiran D. Pawar ${ }^{3}$, Kalim Ullah ${ }^{4}$ (D), Praveen Rahi ${ }^{5}$, \\ Radhakrishna S. Pandit ${ }^{2, *}$ and Jianzhong Sun ${ }^{1, *(\mathbb{D})}$ \\ 1 Biofuels Institute, School of the Environment and Safety Engineering, Jiangsu University, \\ Zhenjiang 212013, China; mudasir.dar@unipune.ac.in or 5501900034@ujs.edu.cn (M.A.D.); \\ rrxie@ujs.edu.cn (R.X.) \\ 2 Department of Zoology, Savitribai Phule Pune University, Ganeshkhind, Pune 411007, India; \\ neerajadhole420@gmail.com \\ 3 School of Nanoscience and Biotechnology, Shivaji University, Vidyanagar, Kolhapur 416004, India; \\ kdp.snst@unishivaji.ac.in \\ 4 School of Medicine, Jiangsu University, Zhenjiang 212013, China; kalimbtk@gmail.com \\ 5 National Centre for Microbial Research, Trinity Complex, Pashan, Pune 411021, India; pravin@nccs.res.in \\ * Correspondence: rspandit@unipune.ac.in (R.S.P.); jzsun1002@ujs.edu.cn (J.S.) \\ + Co-first author.
}

Citation: Dar, M.A.; Dhole, N.P.; Xie, R.; Pawar, K.D.; Ullah, K.; Rahi, P.; Pandit, R.S.; Sun, J. Valorization Potential of a Novel Bacterial Strain, Bacillus altitudinis RSP75, towards Lignocellulose Bioconversion: An Assessment of Symbiotic Bacteria from the Stored Grain Pest, Tribolium castaneum. Microorganisms 2021, 9, 1952. https://doi.org/10.3390/ microorganisms 9091952

Academic Editor: Alberto Scoma

Received: 12 August 2021

Accepted: 9 September 2021

Published: 14 September 2021

Publisher's Note: MDPI stays neutral with regard to jurisdictional claims in published maps and institutional affiliations.

Copyright: (c) 2021 by the authors. Licensee MDPI, Basel, Switzerland. This article is an open access article distributed under the terms and conditions of the Creative Commons Attribution (CC BY) license (https:// creativecommons.org/licenses/by/ $4.0 /)$.

\begin{abstract}
Bioconversion of lignocellulose into renewable energy and commodity products faces a major obstacle of inefficient saccharification due to its recalcitrant structure. In nature, lignocellulose is efficiently degraded by some insects, including termites and beetles, potentially due to the contribution from symbiotic gut bacteria. To this end, the presented investigation reports the isolation and characterization of cellulolytic bacteria from the gut system of red flour beetle, Tribolium castaneum. Out of the 15 isolated bacteria, strain RSP75 showed the highest cellulolytic activities by forming a clearance zone of $28 \mathrm{~mm}$ in diameter with a hydrolytic capacity of $\sim 4.7$. The MALDI-TOF biotyping and 16S rRNA gene sequencing revealed that the strain RSP75 belongs to Bacillus altitudinis. Among the tested enzymes, B. altitudinis RSP75 showed maximum activity of $63.2 \mathrm{IU} / \mathrm{mL}$ extract for xylanase followed by $\beta$-glucosidase $(47.1 \pm 3 \mathrm{IU} / \mathrm{mL}$ extract) which were manifold higher than previously reported activities. The highest substrate degradation was achieved with wheat husk and corn cob powder which accounted for $69.2 \%$ and $54.5 \%$, respectively. The scanning electron microscopy showed adhesion of the bacterial cells with the substrate which was further substantiated by FTIR analysis that depicted the absence of the characteristic cellulose bands at wave numbers 1247,1375 , and $1735 \mathrm{~cm}^{-1}$ due to hydrolysis by the bacterium. Furthermore, B. altitudinis RSP75 showed co-culturing competence with Saccharomyces cerevisiae for bioethanol production from lignocellulose as revealed by GC-MS analysis. The overall observations signify the gut of T. castaneum as a unique and impressive reservoir to prospect for lignocellulose-degrading bacteria that can have many biotechnological applications, including biofuels and biorefinery.
\end{abstract}

Keywords: red flour beetle; gut system; cellulose degradation bacteria; lignocellulose; hydrolyzed biomass; bioethanol

\section{Introduction}

The rapid depletion of fossil fuels and increased emission of greenhouse gases are the major issues of modern civilization that demand immediate addressal. Consequently, these issues have attracted much attention from scientists and academicians as well as policy makers all over the world. Therefore, in recent decades, more focus has been given to prioritizing the production of biofuels from renewable and sustainable resources like 
lignocellulose. Lignocellulosic (LC) plant matter is the most abundant and renewable energy resource that originates from agriculture, industry, municipality, and forestry [1]. Every year, agricultural practices alone contribute millions of tons of solid wastes in the form of rice straw, wheat straw, corn stover (CS), sugarcane bagasse (SCB), etc. [2]. LCbased agro-waste is mostly composed of three polymers, cellulose, hemicellulose, and lignin, among which cellulose and hemicellulose represent a major reservoir of fermentable sugars. Using advanced technologies, this promising, low-cost, and renewable energy resource can be transformed into a variety of useful products such as amino acids, sugars, biofuels, etc.

The biological hydrolysis rendered by some enzymes is foreseen as a promising strategy for bioconversion and utilization of LC biomass [3] because it offers pure and sustainable by-products $[4,5]$. Due to the recalcitrant and heterogeneous nature of LC, the biological conversion relies on multiple enzymes such as cellulases, xylanases, and laccases [6]. However, cellulases and xylanases are the key enzymes that can be employed for the bioconversion of LC biomass into useful products. In nature, these enzymes are secreted by some natural biomass utilization systems (NBUSs) such as bacteria, fungi, insects, annelids, mollusks, and nematodes [7-9]. The underlying mechanisms by which these NBUSs degrade cellulose could potentially valorize the LC biomass into commodity chemicals [10]. Among the NBUSs, insects have evolved the most efficient and sophisticated bioconversion systems through synergism with symbiotic gut microbiota, particularly bacteria [11]. To date, a considerable diversity of cellulose-degrading bacteria has been explored from a variety of insects [12]. Although many cellulose-degrading microorganisms have been reported from different environments, the efficient and economical bioconversion of LC into monomer sugars still remains a challenge. Moreover, the current cellulolytic technologies are not sufficient for the production of 3rd generation bioethanol [13], thus prospection for more efficient bacterial strains is direly important to make biofuel production economical.

Being the most diverse and dominant class in the kingdom Animalia, Insecta possess superior adaptations to a variety of foods and environmental conditions. One such insect, the red flour beetle, Tribolium castaneum Herbst (Coleoptera: Tenebrionidae), is a stored grain pest with economic importance $[14,15]$. It attacks many important crops such as wheat, maize, peanuts, cashews, etc. [16,17], and causes qualitative and quantitative loss of grain productivity. Apart from cereals and grains, it predominantly feeds on wheat bran which is a rich source of fibrous polysaccharides such as xylan and cellulose [18]. Although the occurrence of endogenous cellulases in T. castaneum was reported recently [19-22], not much is known about the cellulolytic microbes inhabiting its gut system. Additionally, unlike other insects such as termites [23,24], Lepidoptera [12,25], orthopterans [26], and dung beetles [27,28], bacterial cellulases and their activities from the gut of T. castaneum have not been studied yet. Hence, the prospection of cellulolytic bacteria in T. castaneum would not only contribute to the basic understanding of host-microbe interactions but would also highlight its prospective applications for the discovery and bioengineering of potential bacteria and their use in biorefinery and pulp industry alongside biofuel production. Given this importance, the objectives of the present study were to explore the cellulolytic bacteria from the gut system of T. castaneum, then identify and screen them for cellulose degradation. Further, the cellulolytic potential of the most efficient bacterial strain was evaluated and characterized for the production of LC-hydrolyzing enzymes that can be employed to break down various agricultural wastes, such as SCB, corncob powder $(\mathrm{CCP})$, wheat husk (WH), grass straw (GS), etc., into many commodity products such as reducing sugars, biofuels, etc.

\section{Materials and Methods}

\subsection{Reagents and Substrates}

Agricultural wastes including corncobs, WH, GS, and SCB were acquired from the rural areas of the Pune district of Maharashtra, India. These substrates were pre-treated mildly with an alkaline solution $(0.1 \mathrm{~N})$ of sodium hydroxide $(\mathrm{NaOH})$ for $24 \mathrm{~h}$ at room tem- 
perature. After pre-treatment, the substrates were prepared as described previously [29], while commercially available substrates such as carboxy methyl cellulose (CMC), microcrystalline cellulose (Avicel $101^{\circledR}$ ), and Whatman ${ }^{\circledR}$ filter paper grade 2 (FP) were procured from Sigma-Aldrich, (Millipore Sigma, St. Louis, MO, USA). The Berg's minimal salt (BMS) media contained different salts in varying proportions as reported earlier [30].

\subsection{Identification and Dissection of Insects}

The insects collected from the wheat husk were identified based on their morphological characteristics [31], particularly head and thoracic regions, using interactive dichotomous keys from Lucid Professional version 2.0 [32] (https:/ / lucidcentral.org/, accessed on 18 March 2021). Before dissection, the adult beetles were starved for $8 \mathrm{~h}$ followed by brief washes of ethanol grades $50 \%$ and $70 \%$ each for $30 \mathrm{~s}$ and lastly of absolute ethanol for $60 \mathrm{~s}$. The insects $(n=20)$ were sacrificed under aseptic conditions and the revealed gut systems were weighed followed by homogenization in $0.4 \mathrm{~mL}$ phosphate-buffered saline (PBS, pH 7.0) by using a micropestle. The homogenized mixture was serially diluted up to $10^{-8}$ and spread on Luria-Bertani (LB) agar plates and BMS agar which contained 0.5\% $\mathrm{CMC}$ as a screen to grow cellulose-degrading bacteria only. The BMS agar plates were incubated at $37^{\circ} \mathrm{C}$ for $48 \mathrm{~h}$ to allow the growth of enriched bacteria.

\subsection{Isolation and Screening for Cellulolytic Bacteria}

After incubation of the BMS-CMC agar plates at $37^{\circ} \mathrm{C}$, the bacterial colonies were picked and streaked individually on LB agar. The fully grown bacterial isolates were then purified through a repeated streak plate technique followed by screening for CMC degradation. The cellulase activities of the isolated bacteria were semi-quantitatively tested by spot inoculation of the individual colonies on BMS-CMC agar plates. The inoculated plates were incubated for the growth of cellulolytic bacteria at $37^{\circ} \mathrm{C}$ for $24-48 \mathrm{~h}$. After the proper growth and incubation, the plates were stained with Gram's iodine staining solution to observe the zone of CMC clearance around the bacterial colonies. The cellulase activity was estimated in terms of hydrolytic capacity (HC) which is defined as the ratio of the diameter of CMC clearance (zone) to the diameter of the bacterial colony. Subsequently, the cellulase-positive bacteria were identified by using the matrix-assisted laser desorption ionization-time of flight (MALDI-TOF) technique and characterized for further analyses.

\subsection{Biotyping by MALDI-TOF}

Initially, the isolated and purified bacteria were identified by the MALDI-TOF method. For biotyping, single colonies of each bacterium were seeded separately into $50 \mathrm{~mL}$ tubes containing freshly prepared LB broth and grown overnight at $37^{\circ} \mathrm{C}$ by shaking at $150 \mathrm{rpm}$. After proper growth, the cultures were centrifuged for $5 \mathrm{~min}$ at $5000 \mathrm{rpm}$ to harvest the bacteria. The samples were prepared by using the method of Schulthess and coworkers [33] with a few modifications. Briefly, the obtained bacterial cells were treated with $600 \mu \mathrm{L}$ distilled water and $1.8 \mathrm{~mL}$ ethanol followed by repeated centrifugation at 10,000 rpm for $2 \mathrm{~min}$ to remove the residual ethanol. The pellets were air-dried thoroughly and resuspended in $40 \mu \mathrm{L}$ formic acid-water (70:30 v/v) solution followed by mixing with an equal volume of acetonitrile. The suspension was centrifuged at 10,000 rpm for $2 \mathrm{~min}$, and $2 \mu \mathrm{L}$ of each supernatant was transferred to the target plate. The bacteria on the target plate were overlayed with $\alpha$-cyano-4-hydrocinnamic acid (CHCA) matrix solution $(1 \mu \mathrm{L}$ for each sample). Biotyper software was employed to compare the sample mass spectra with the mass spectra of reference strains in the MALDI database. The Biotyper software calculated the arbitrary unit scores above 1.85, indicating the similarity between the isolates and reference bacteria. The variations in MALDI-TOF scores were measured by fixing the species cutoff values at $\geq 1.9$ while maintaining genus cutoff values at 1.8 followed by re-interpreting the top 2 matching database records in a Bruker Biotyper system (Bruker, Billerica, MA, USA). 


\subsection{Identification and Phylogenetic Analysis}

For molecular identification, the genomic DNA (gDNA) was extracted from the freshly cultured bacteria by using a soil DNA extraction kit (HiMedia Pvt Ltd., Mumbai, India), and quantified by using a NanoDrop spectrophotometer. The $16 \mathrm{~S}$ rRNA gene was PCR amplified by using the bacteria-specific primer pair 27F (5'-AGAGTTTGATYMTGGCTCAG-3') and 1492R (5'-TACGGYTACCTTGTTACGACTT-3') [34]. The $50 \mu \mathrm{L}$ PCR reaction contained $2 \mu \mathrm{L}(10 \mathrm{ng} / \mathrm{mL})$ of template DNA, $5 \mu \mathrm{L}$ of Taq buffer (Bangalore Genei, India), $0.2 \mathrm{mmol} / \mathrm{L}$ of dNTPs (Bangalore Genei, India), 10 pmol of each primer, and $0.5 \mathrm{U}$ of Taq polymerase (Bangalore Genei, India). The thermal cycling conditions consisted of initial denaturation at $95{ }^{\circ} \mathrm{C}$ for $5 \mathrm{~min}, 35$ amplification cycles of primary denaturation at $94{ }^{\circ} \mathrm{C}$ for $1 \mathrm{~min}$, annealing at $55^{\circ} \mathrm{C}$ for $1 \mathrm{~min}$, and extension at $72{ }^{\circ} \mathrm{C}$ for $1 \mathrm{~min}$, followed by final extension of $7 \mathrm{~min}$ at $72{ }^{\circ} \mathrm{C}$. The PCR products were checked for size and purity on $1.2 \%(w / v)$ agarose gels, and then sequenced by using the ABI Big-Dye version 3.1 sequencing kit as per the manufacturer's instructions. The obtained $16 \mathrm{~S}$ rDNA sequences were edited manually using ChromasPro software (http:/ / www.technelysium.com.au/ChromasPro.html, accessed on 12 March 2021) and then compared with closely related sequences in the NCBI database (http:/ / www.ncbi.nlm.nih.gov, accessed on 18 February 2021) using the BLASTn program. The phylogenetic tree was reconstructed in the MEGA X program [35] by maintaining a bootstrap value of 100. The phylogenetic tree was annotated in FigTree software v1.4.3. The $16 \mathrm{~S}$ rDNA gene sequences of the reference strain and isolated bacterium-encoded RSP75 were aligned in the EMBOSS: dotmatcher program [36] using a window size of 30 and threshold value 40 .

\subsection{Biochemical Characterization}

The morphological and cultural characteristics, such as colony appearance, cell shape, cell motility, etc., of the potential strain were determined by microscopy. Other tests, such as catalase, Methyl Red (MR) and Voges-Proskauer (VP) reactions, indole production, citrate utilization, and hydrolysis of sugars or nitrogenous compounds, were carried out by using the HiBacillus test kit. The HiBacillus ${ }^{\mathrm{TM}}$ identification kit is a standardized micromethod that combines 12 conventional and assimilation test sets to identify purified bacteria (HiMedia Pvt. Ltd.). The inoculated strips of the kit system were incubated for 18 to $24 \mathrm{~h}$ at $37^{\circ} \mathrm{C}$ then they were read by referring to the standardized interpretation tables.

\subsection{Effect of $\mathrm{pH}$ and Temperature on Cellulase Activity}

To check the effect of $\mathrm{pH}$ on bacterial growth and cellulolytic activity, the isolate was grown at $37^{\circ} \mathrm{C}$ for $24-48 \mathrm{~h}$ on BMS-CMC agar media with different $\mathrm{pH}$ in the range of 3.0-9.0. For optimization of temperature, the test isolate was grown for $24 \mathrm{~h}$ on the medium with optimum $\mathrm{pH}$ at different temperatures ranging from $30-50{ }^{\circ} \mathrm{C}$. After incubation, the plates were stained with Gram's iodine solution to check the zone of CMC clearance around the colony. The $\mathrm{CMC}$ clearance zones were measured by using the procedure as described above.

\subsection{Growth Curve}

To assess the growth pattern of the potential bacterium, a single colony was inoculated in BMS broth containing 0.5\% CMC as the sole source of carbon and agitated at $150 \mathrm{rpm}$ and $37^{\circ} \mathrm{C}$. The optical density (OD) was documented every $8 \mathrm{~h}$ using a side-arm flask till the bacteria achieved a declining phase. The OD and transmittance of the samples were recorded at $\lambda 600$ on a colorimeter.

\subsection{Enzyme Assays}

To determine the production of lignocellulolytic enzymes, the BMS broth containing $0.5 \%(w / v)$ of different substrates, such as CCP, SD, GS, WH, FP, and SCB, in individual flasks were inoculated with $1 \%$ of freshly prepared bacterial cultures and incubated for 14 days by agitating at $150 \mathrm{rpm}, 37^{\circ} \mathrm{C}$. The sample aliquots collected after different time 
intervals were centrifuged at $12,000 \mathrm{rpm}$ for $10 \mathrm{~min}$ and $4{ }^{\circ} \mathrm{C}$. The supernatants obtained were treated as crude enzyme extracts. The endoglucanase and xylanase assays were estimated as described previously [30]. The $\beta$-glucosidase assay was carried out as per the method of Gao and colleagues [37] with minor changes. Briefly, $1 \mathrm{~mL}$ of $0.2 \%$ cellobiose in sodium citrate buffer was treated with $1 \mathrm{~mL}$ of enzyme extract. After incubation for $60 \mathrm{~min}$ at $40{ }^{\circ} \mathrm{C}$, the reaction was terminated by adding $3 \mathrm{~mL}$ of 3,5-dinitrosalicylic acid reagent (DNSA) and boiling for $5 \mathrm{~min}$ in a water bath. The glucoamylase activity was assayed by mixing $250 \mu \mathrm{L}$ of the substrate (1\% starch in PBS, pH 7.4) with $250 \mu \mathrm{L}$ of the enzyme. The reactions were carried out at $40{ }^{\circ} \mathrm{C}$ for $10 \mathrm{~min}$ and then terminated with $750 \mu \mathrm{L}$ of DNSA reagent [38]. Thereafter, the reaction mixtures were boiled for $5 \mathrm{~min}$ in a water bath to denature the enzyme and allow color change. Finally, the absorbances were recorded spectrophotometrically at $\lambda 540$ and the reducing sugars were estimated by using glucose as standard for endoglucanase and $\beta$-glucosidase assays. However, xylose was used as standard sugar for xylanase estimation. The protein concentration in the enzyme extracts was determined by Lowry's method [39] using bovine serum albumin (BSA) as standard. The enzyme activities were calculated in international units (IU) where 1 IU of activity is defined as the amount of enzyme required to liberate $1 \mu \mathrm{Mol}$ of glucose equivalents per min under the standard assay conditions.

\subsection{Determination of Substrate Degradation Ratio}

The effect of bacterial treatment on the degree of substrate degradation was characterized by seeding $1 \mathrm{~mL}$ of freshly prepared inoculum (OD600:0.5) in BMS media containing $1000 \mathrm{mg}$ of individual substrates as carbon sources. The culture media were incubated on a rotary shaker at $37^{\circ} \mathrm{C}$ and $150 \mathrm{rpm}$. During the incubation period, the culture flasks were continuously checked for a change in turbidity of the media and bacterial growth as a measure of degradation of the substrates. The inoculated culture media containing different substrates, viz., CCP, FP, GS, SCB, SD, and WH, were incubated for up to 8 days. The substrate degradation ratio was calculated using the method described by Du and coworkers [40] with a few modifications. The culture broth after proper incubation was centrifuged at 12,000 rpm for $15 \mathrm{~min}$ to recover the unused substrates as biomass. The pellet containing biomass with bacterial cells was treated with acetic-nitric acid reagent (1 M) followed by a wash of distilled water. Subsequently, the biomass was washed with absolute ethanol for $20 \mathrm{~min}$ for complete removal of the bacterial debris. The unused substrates were then air-dried and finally weighed to measure the residual LC. The respective controls contained individual substrates but no bacterial treatments. The percent (\%) substrate degradation was defined as the ratio of the final weight of substrates to the initial weight of substrates.

\subsection{Electron Microscopy and Characterization of Hydrolyzed Substrate}

The characterization and comparison of the treated and untreated substrates were carried out by various techniques such as field emission scanning electron microscopy (FESEM) and Fourier transform infrared spectroscopy (FTIR). The hydrolysis of the FP was analyzed as described previously [41]. For these analyses, the freshly prepared BMS media containing individual substrates, such as CCP, FP, SCB, WH, etc., were seeded with $1 \%$ of the bacterial inoculum, and incubated at $37^{\circ} \mathrm{C}, 150 \mathrm{rpm}$. After incubation, the broth was centrifuged at $5000 \mathrm{rpm}$ for $5 \mathrm{~min}$ to harvest the biomass containing bacterial cells. For FESEM analysis, the samples were prepared by using the method of Galabova et al. [42]. The specimens were adequately air-dried and coated with $100 \AA$ gold and then observed at a voltage of $10 \mathrm{kV}$ in a Nova Nano SEMNPEP 303 (FEI Technologies, Oregon, USA). 
For functional group analysis, the FTIR spectroscopy was carried out for FP that was used as the sole source of carbon for bacterial growth. The FP discs $(10 \mathrm{mg})$ obtained from bacterial treatment and control experiments were individually mixed with $1000 \mathrm{mg}$ of spectroscopy grade potassium bromide $(\mathrm{KBr})$ in an agate mortar and subsequently pressed into discs. The infrared (IR) spectra were examined on an FTIR spectrometer (Jasco 6100 , Germany). The FTIR spectra of the hydrolyzed and untreated FP were recorded in the absorption band mode ranging from 400 to $4000 \mathrm{~cm}^{-1}$ with a resolution of $4 \mathrm{~cm}^{-1}$ accumulating 32 scans.

\subsection{GC-MS Analysis}

To determine the byproducts of saccharification and fermentation, freshly prepared BMS medium containing WH as substrate was inoculated with freshly grown potential bacteria, and incubated at $150 \mathrm{rpm}$ for 8 days to allow the accumulation of reducing sugars. Based on the higher enzyme activities and degradation of the tested agro-wastes as substrates, WH was selected as a sole source of carbon for the saccharification purpose. After the incubation period, the medium-containing flasks were seeded with $0.1 \%$, of Saccharomyces cerevisiae for fermentation of the reducing sugars. The media were incubated at $30^{\circ} \mathrm{C}$ for $48 \mathrm{~h}$ followed by centrifugation at $10,000 \mathrm{rpm}$ for $10 \mathrm{~min}$ to obtain the supernatant. The acquired supernatants were subjected to filtration through a $0.2 \mu \mathrm{m}$ syringe filter. Finally, the ethanol formed was estimated by GC-MS analysis using the method previously described by Bagewadi and colleagues [43]. The identity of the mass spectroscopic peaks was confirmed from the database of the National Institute of Standards and Technology (NIST). However, the survey was restricted to mass numbers 15, 30, 42, and 45 where fermentation products yield the majority of ions.

\subsection{Statistical Analyses}

The data were analyzed statistically by one-way analysis of variance (ANOVA) using Tukey's test to determine the degree of significance in SPSS software version 22 (IBM SPSS, New York, NY, USA). A $p$ value $<0.01$ is considered significant. The obtained results are demonstrated as mean \pm standard deviation of three independent replicates unless stated otherwise. The graphs were plotted in Origin software version 8.1 (Origin Lab. Corporation, Northampton, MA, USA).

\section{Results}

\subsection{Identification of the Insect}

In the present study, the collected insects were identified by using dichotomous keys based on morphological characteristics and then confirmed by the Zoological Survey of India, Pune, India. The "armor-like" elytra hiding the membranous hind wings showed that the collected insect was a beetle species. Further, reddish-brown color, approximately $3 \mathrm{~mm}$ long, with a flattish body and curved thorax (Figure 1a-c) confirmed it as a red flour beetle, Tribolium castaneum. The head and upper part of the thorax were covered with minute punctures and the wing cases (elytra) were ridged along their length. Capitate antennae were enlarged with the last three segments prominently wider than the proximal segments. Moreover, some of the beetles were observed to show short flights during experimentation. 


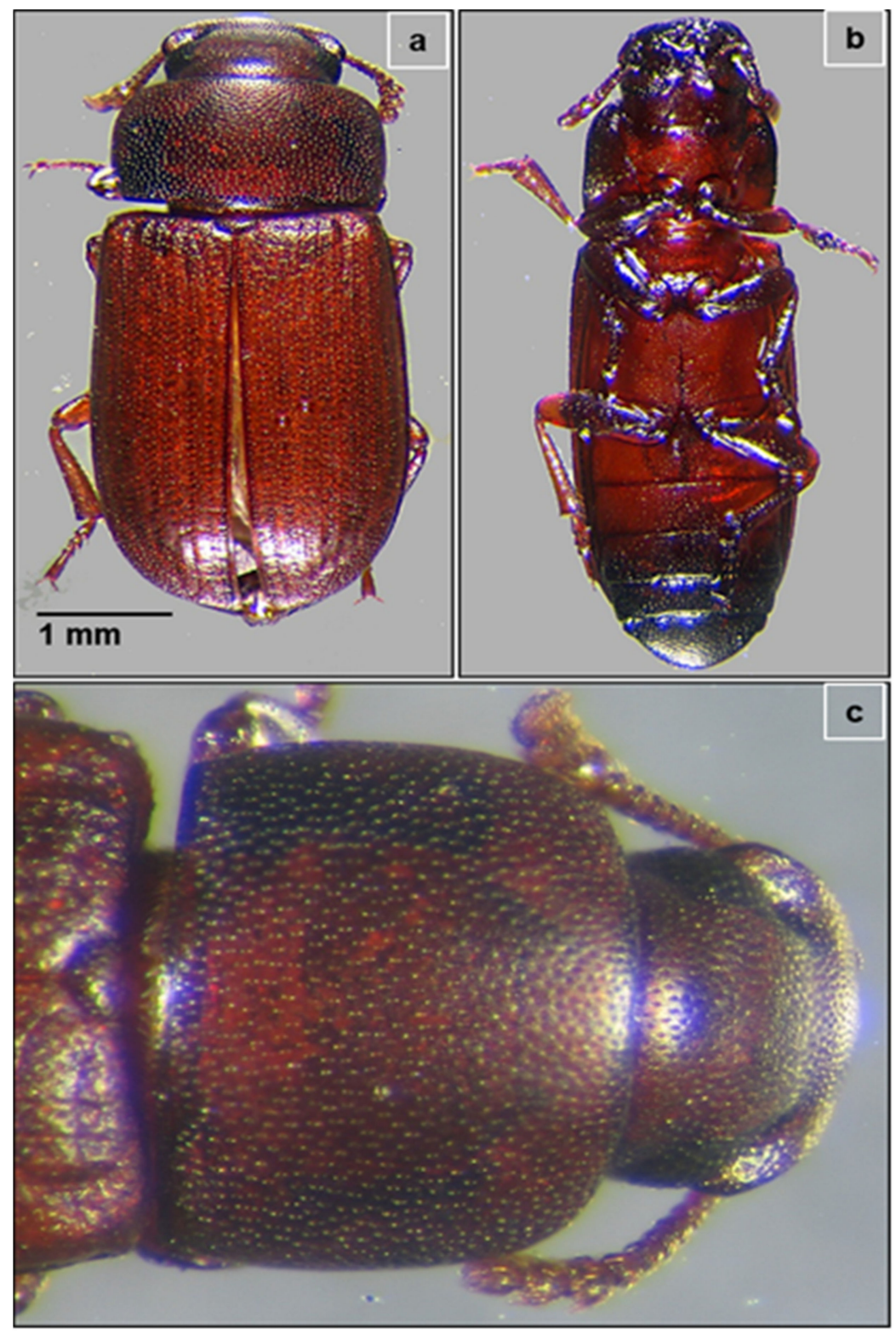

Figure 1. The red flour beetle, Tribolium castaneum. (a) Dorsal view showing the flattish curvedsided body covered with minute punctures. Ventral view of the whole body of adult beetle (b), and magnified view of the thorax with prominently large eyes and capitate antennae with broad segments (c).

\subsection{Isolation and Identification of Bacteria by MALDI-TOF}

When the gut extracts were spread on BMS-CMC and LB agar media, many bacterial isolates grew on LB agar plates. However, after the repeated streaking on BMS-CMC agar media, 15 isolates were sustained and grew, indicating their potential to utilize CMC. Since MALDI-TOF-based identification is faster and more accurate than traditional biochemical characterization, it was employed to identify the bacteria isolated from the beetle gut. The Biotyper software-based comparison resulted in an arbitrary unit score ranging from 1.802 to 2.244 , reflecting the similarity of the isolated bacterial species to reference spectra of best matches from the database. The MALDI-TOF analyses affiliated isolates to genera including Bacillus, Citrobacter, Kluyvera, Escherichia, Enterococcus, and Achromobacter, considering mass spectroscopic scores of over 1.8 (Table 1). Based on MALDI-TOF analysis, the isolate encoded RSP75 was identified as Bacillus species with a unit score of 2.207. 
Table 1. MALDI-TOF mass spectrometry-based biotyping of bacteria isolated from the gut system of the red flour beetle, T. castaneum.

\begin{tabular}{cccc}
\hline Sr. No. & Isolate Code & Best Hit & MALDI-TOF Score \\
\hline 1 & TC5 & Achromobacter spanius & 2.057 \\
2 & TC7 & Escherichia hermannii & 1.824 \\
3 & TC10 & Bacillus subtilis & 1.946 \\
4 & TC11 & Bacillus sp. & 1.806 \\
5 & TC16 & Enterococcus faecalis & 1.855 \\
6 & TC18 & Entrobacter freundii & 1.851 \\
7 & TC24 & Achromobacter insolitus & 2.157 \\
8 & TC27 & Bacillus subtilis & 2.244 \\
9 & TC39 & Kluyvera georgiana & 1.802 \\
10 & TC41 & Bacillus sp. & 2.244 \\
11 & TC55 & Cronobacter sakazakii & 2.218 \\
12 & TC67 & Escherichia coli & 1.828 \\
13 & TC70 & Bacillus sp. & 1.883 \\
14 & RSP75 & Kluyvera ascorbata & 2.207 \\
15 & TC91 & & 1.915 \\
\hline
\end{tabular}

\subsection{Screening and Selection of the Potential Bacteria}

Of the 15 bacterial cultures that were isolated and grown on BMS-CMC agar media, 12 isolates showed varying cellulolytic activity evident from zones of CMC clearance in the range of 4 to $28 \mathrm{~mm}$ in diameter (Figure S1A). Among these, $46.66 \%$ bacteria showed lower activity from $4-10 \mathrm{~mm}$ whereas $26.66 \%$ showed medium activity ( 11 to $20 \mathrm{~mm}$ ). Noteworthily, the isolate RSP75 showed a larger zone of CMC clearance measuring $28 \mathrm{~mm}$ in diameter. As $20 \%$ of the isolates did not show any activity, they were eliminated from further study. The hydrolytic capacity ratio of the cellulase-positive isolates ranged from 1.5 to 5.5 (Figure S1B). Since RSP75 showed maximum cellulolytic potential, it was selected for further analysis and identified by a molecular phylogenetic approach.

\subsection{Molecular Identification and Phylogenetic Analysis of the Bacteria}

The selected isolate with a potential cellulose-degrading repertoire was identified by $16 \mathrm{~S}$ rRNA gene sequencing and amplification. The BLASTn analysis and phylogenetic reconstruction of the RSP75 showed over $99.46 \%$ sequence similarity to Bacillus altitudinis. The $16 \mathrm{~S}$ rRNA sequence similarity of RSP75 was also confirmed by EZbiocloud (https: / / www.ezbiocloud.net/identify, accessed on 5 July 2021) where it showed $99.23 \%$ similarity to $B$. altitudinis $41 \mathrm{KF} 2 \mathrm{~b}(\mathrm{~T})$. Further, upon the phylogenetic reconstruction, RSP75 formed a cluster with B. altitudinis, therefore, it is hereafter referred as B. altitudinis RSP75 (Figure 2). The two-dimensional matrix plot showed a slight frameshift between the 16S rRNA gene sequences of the reference strain and B. altitudinis RSP75 (Figure S2). This slight frameshift could have resulted from mutations due to differences in habitat and corresponding metabolic shifts of the bacteria. The $16 \mathrm{~S}$ rRNA gene sequence of B. altitudinis RSP75 can be accessed from the NCBI database under accession number MW559543. 


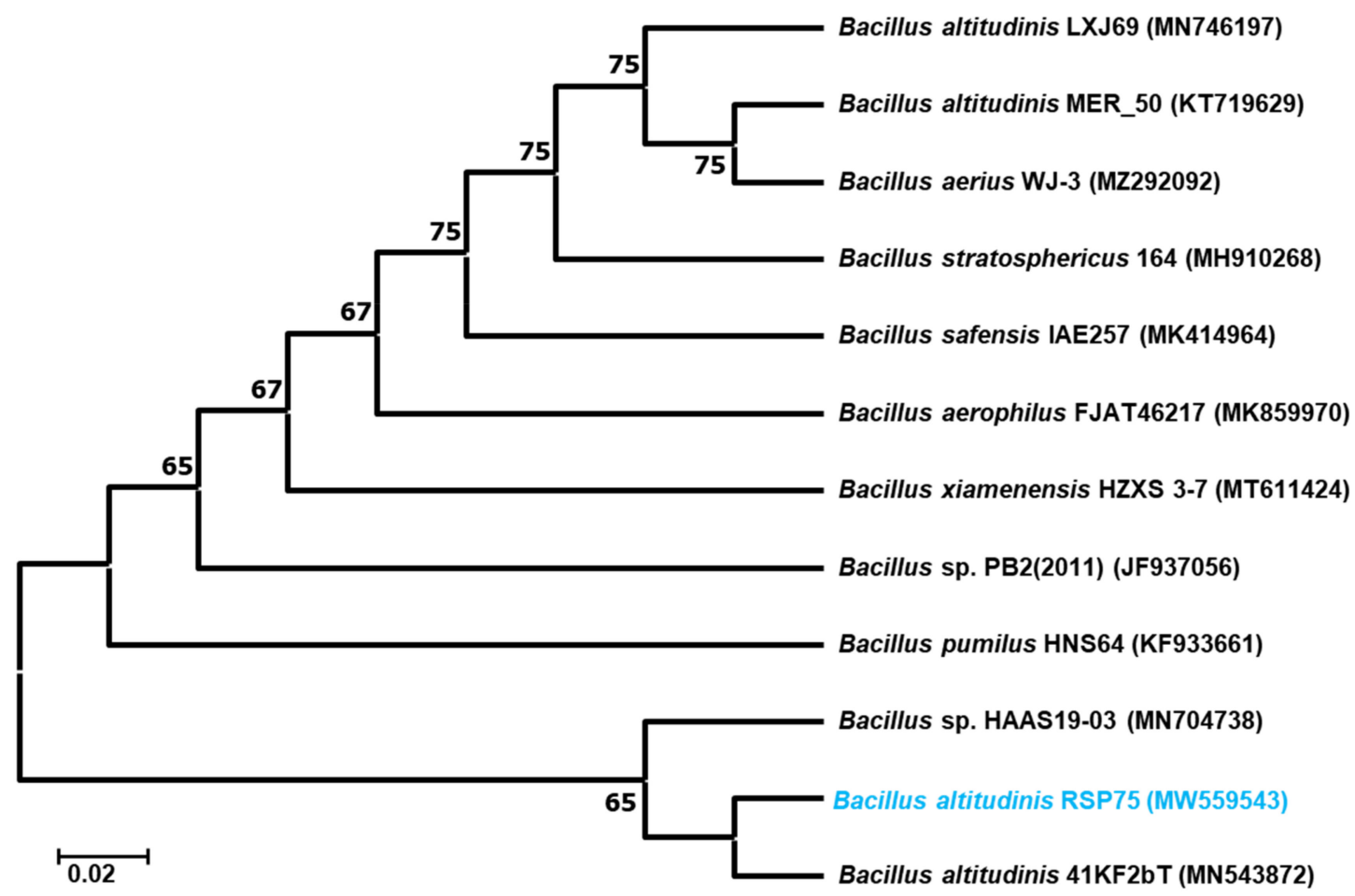

Figure 2. The phylogenetic reconstruction of B. altitudinis RSP75 generated by the neighbor-joining method in MEGA X, showing its relationships with closely related bacterial species from NCBI. Accession numbers are given in parentheses, and the bootstrap values are shown on nodes when above 60 . Scale bar represents 0.02 Jukes-Cantor distances.

\subsection{Biochemical and Growth Curve Analyses}

The principle of biological identification is based on the ability of bacteria to metabolize particular types of chemical compounds. The biochemical analysis indicated that B. altitudinis RSP75 utilizes a variety of carbon and nitrogen sources, such as ornithine, phenylalanine, sucrose, glucose, mannose, and cellobiose. In addition, the bacterium was also found positive in the Voges-Proskauer test. Subsequently, B. altitudinis RSP75 also showed enzyme activities, namely $\beta$-glucosidase, pyrrolidonylarylamidase (PYR), and hydrolysis of $p$-nitrophenyl $\beta$-D-glucopyranoside. However, it showed negative reactions towards substrates such as lysine, urease, indole, sorbitol, trehalose, melibiose, salicin, raffinose, lactose, etc. Similarly, it also lacked $\alpha$-galactosidase and $\beta$-xylosidase activities. Bacillus altitudinis RSP75 showed oxidation of glucose in the Methyl Red test. Moreover, B. altitudinis RSP75 initially exhibited very slow growth on BMS-CMC media up to $16 \mathrm{~h}$, which was followed by continuous increments from 16 to $72 \mathrm{~h}$ (Figure 3). The growth curve profile further displayed a declining trend in cell growth after $80 \mathrm{~h}$. 


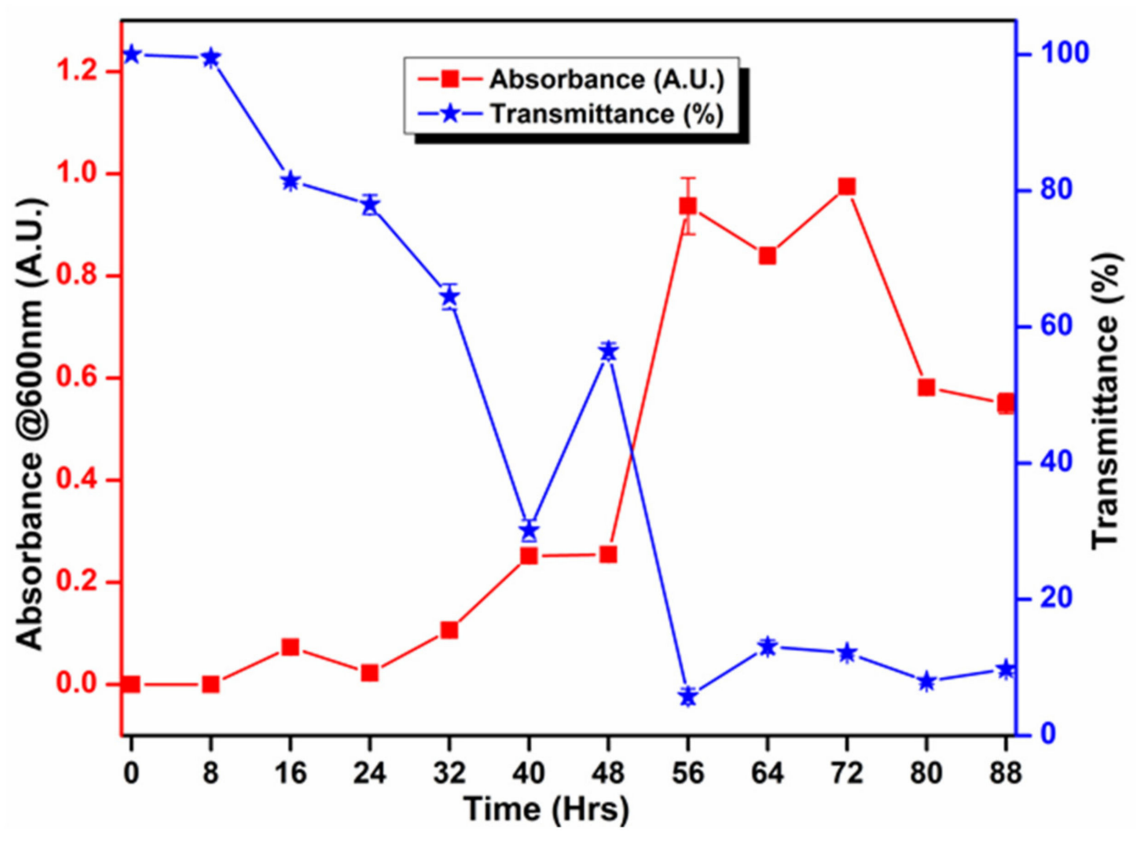

Figure 3. Growth pattern of B. altitudinis RSP75 in BMS medium supplemented with CMC as the sole source of carbon.

\subsection{Optimization of $\mathrm{pH}$ and Temperature for the Bacterium}

The physicochemical parameters, such as $\mathrm{pH}$ and temperature, of culture media are well known to influence the metabolism and catalytic efficiency of bacteria. The gut bacterium B. altitudinis RSP75 isolated in the present study showed good cellulolytic activities at $\mathrm{pH} 5.0(p<0.001)$, indicating it as the most suitable $\mathrm{pH}$ for cellulose degradation (Figure 4A). Thus, B. altitudinis RSP75 showed more efficiency at acidic $\mathrm{pH}$ than in alkaline conditions. Similarly, study of the effect of temperature demonstrated maximum activity $(27.5 \pm 0.7 \mathrm{~mm})$ at $37^{\circ} \mathrm{C}$, indicating the mesophilic nature of B. altitudinis RSP75 $(p<0.001)$. Although the activity at $50^{\circ} \mathrm{C}$ was 1.6 -fold higher than at $30^{\circ} \mathrm{C}$, it was much lower than the activity observed at $37^{\circ} \mathrm{C}$ (Figure 4B).
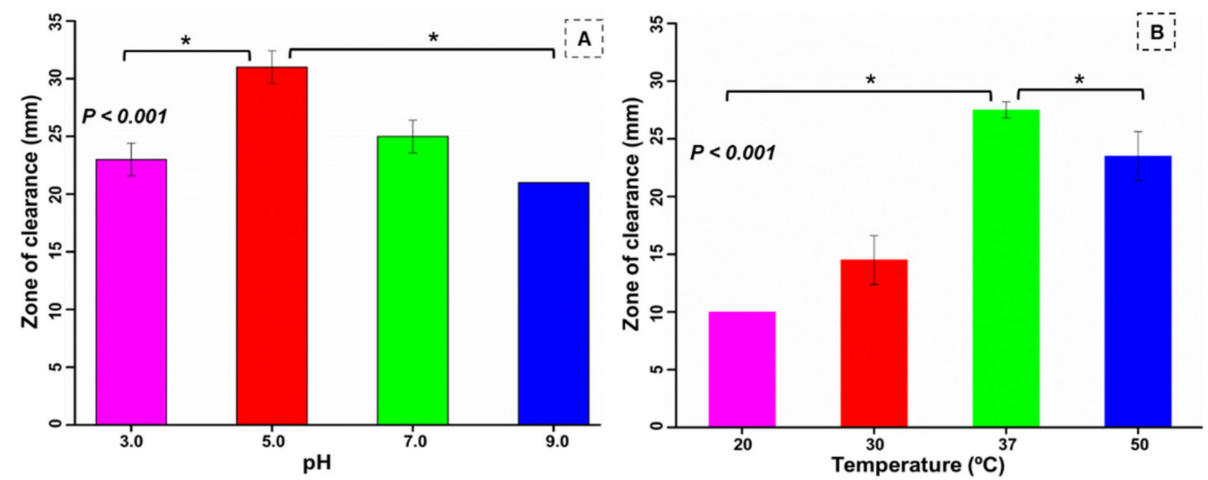

Figure 4. Effect of $\mathrm{pH}(\mathbf{A})$ and temperature (B) on the cellulose-degrading activity of the potential bacterium. Results are presented as average \pm standard deviation of five experimental replicates. The asterisk $\left({ }^{*}\right.$ ) over the bars indicates $p$ value statistically significant at $<0.01$ for optimum $\mathrm{pH}$ ( $\mathrm{pH}$ 5.0) and temperature $\left(37^{\circ} \mathrm{C}\right)$ when compared with other related conditions.

\subsection{Enzyme Assays}

Among the tested substrates, higher activities were achieved on substrates such as $\mathrm{FP}, \mathrm{WH}, \mathrm{SD}$, and GS as compared to CCP and SCB. The highest endoglucanase activity of $9.08 \pm 1 \mathrm{IU} / \mathrm{mL}$ extract, also known as CMCase activity, was exhibited by B. altitudinis 
RSP75 on FP (Figure S3a) followed by WH $(8.89 \pm 1.9 \mathrm{IU} / \mathrm{mL}$ extract) as substrates after 8 days of incubation. However, the lowest endoglucanase activity of $2.34 \mathrm{IU} / \mathrm{mL}$ extract was found with SCB as substrate on the first day of incubation. Similar to the endoglucanase assay, the highest $\beta$-glucosidase activities $(47.1 \pm 3.7$ and $36.3 \pm 6.3 \mathrm{IU} / \mathrm{mL}$ extract) were produced when B. altitudinis RSP75 was grown continuously for up to 8 days on FP and $\mathrm{WH}$, respectively. In the case of $\beta$-glucosidase, the lowest activity $(1.81 \mathrm{IU} / \mathrm{mL}$ extract) was achieved with SCB as the sole source of carbon on the 4th day of incubation. Among the tested agro-wastes used as substrates, the highest $\beta$-glucosidase activities were produced on $\mathrm{WH}$, followed by SD and CCP. For xylanase activity, a unique trend of substrate preference was observed as a higher enzyme production of $63.2 \pm 13 \mathrm{IU} / \mathrm{mL}$ extract was noted after 8 days of incubation on FP followed by CCP $(60.2 \mathrm{IU} / \mathrm{mL}$ extract), indicating them as favorable substrates among the tested agro-wastes. On WH as a carbon source, the highest xylanase activity of $58.81 \mathrm{IU} / \mathrm{mL}$ extract (though lower than the activity on FP) was achieved after 4 days of incubation. However, the lowest xylanase activity of $7.78 \pm 1.7 \mathrm{IU} / \mathrm{mL}$ extract was determined on day 1 , when B. altitudinis RSP75 grew on SCB as substrate. In the case of glucoamylase activity, the highest activity of $15.05 \pm 0.1 \mathrm{IU} / \mathrm{mL}$ extract was exhibited after 8 days on FP used as a sole source of carbon. After FP, the glucoamylase activity followed a trend of $\mathrm{WH}>\mathrm{SCB}>\mathrm{CCP}$ with $13.6 \pm 3,12.3 \pm 0.9$, and $10.9 \pm 0.8 \mathrm{IU} / \mathrm{mL}$ of extracts, respectively. The maximum glucoamylase activity on GS was observed after 14 days of incubation, demonstrating a value of $9.42 \mathrm{IU} / \mathrm{mL}$ extract. Among the tested substrates, glucoamylase activity was lower using GS and SD as carbon sources. During the period of incubation, the enzyme activities were better on the 8th day, therefore this was taken into consideration for further analysis. Among the tested agro-wastes used as substrates, the overall enzyme activities were higher on $\mathrm{WH}$. The enzymatic profile signified that the potential bacterium showed higher potential (eight-fold) for xylanase activity when compared with CMCase $(p<0.001)$. After xylanase, the potential bacterium showed maximum activities towards $\beta$-glucosidase, as shown in Figure 5A. Furthermore, the sugar production was highest in the case of FP and then $\mathrm{WH}$, indicating them as potential carbon sources for fermentation (Figure 5B).
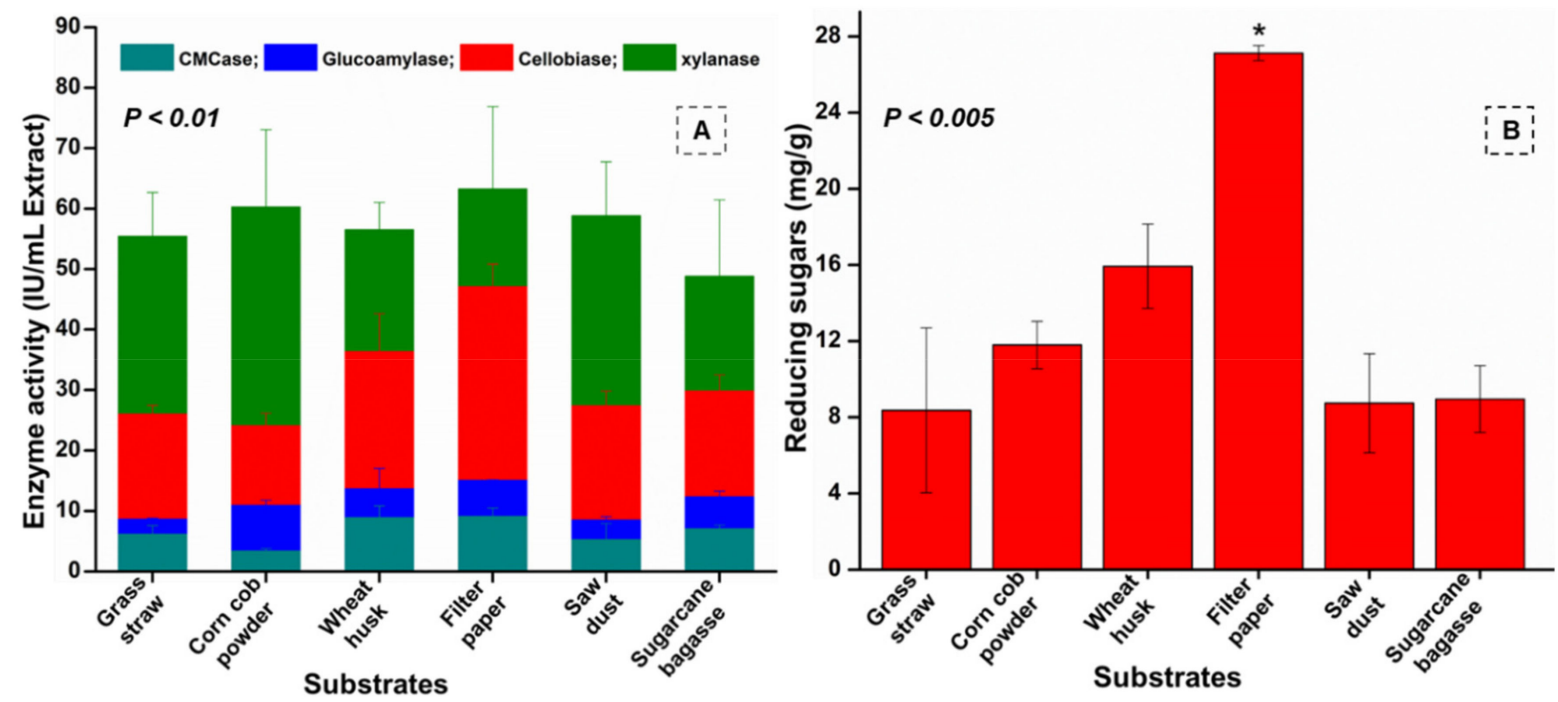

Figure 5. (A) Profile of the enzyme activities of B. altitudinis RSP75 on different carbon sources used as substrates after 8 days of incubation. (B) Reducing sugar production by B. altitudinis RSP75 on different substrates. The asterisk $\left(^{*}\right)$ indicates reducing sugar production statistically significant at $p<0.005$ on FP when compared with other substrates.

\subsection{Determination of Substrate Degradation Ratio}

Among the substrates, B. altitudinis RSP75 demonstrated the highest degradation of WH (69\%) followed by CCP (54\%; Figure 6). Being recalcitrant and purely cellulosic, 
FP was degraded the least (11\%) among the tested carbon sources. The degradation of the substrates showed correlation with substrate compositions, as WH, and CCP are predominantly composed of many five- and six-carbon sugars such as mannose and other hemicelluloses. The biochemical analysis and enzyme assays demonstrated that they were efficiently degraded by B. altitudinis RSP75.

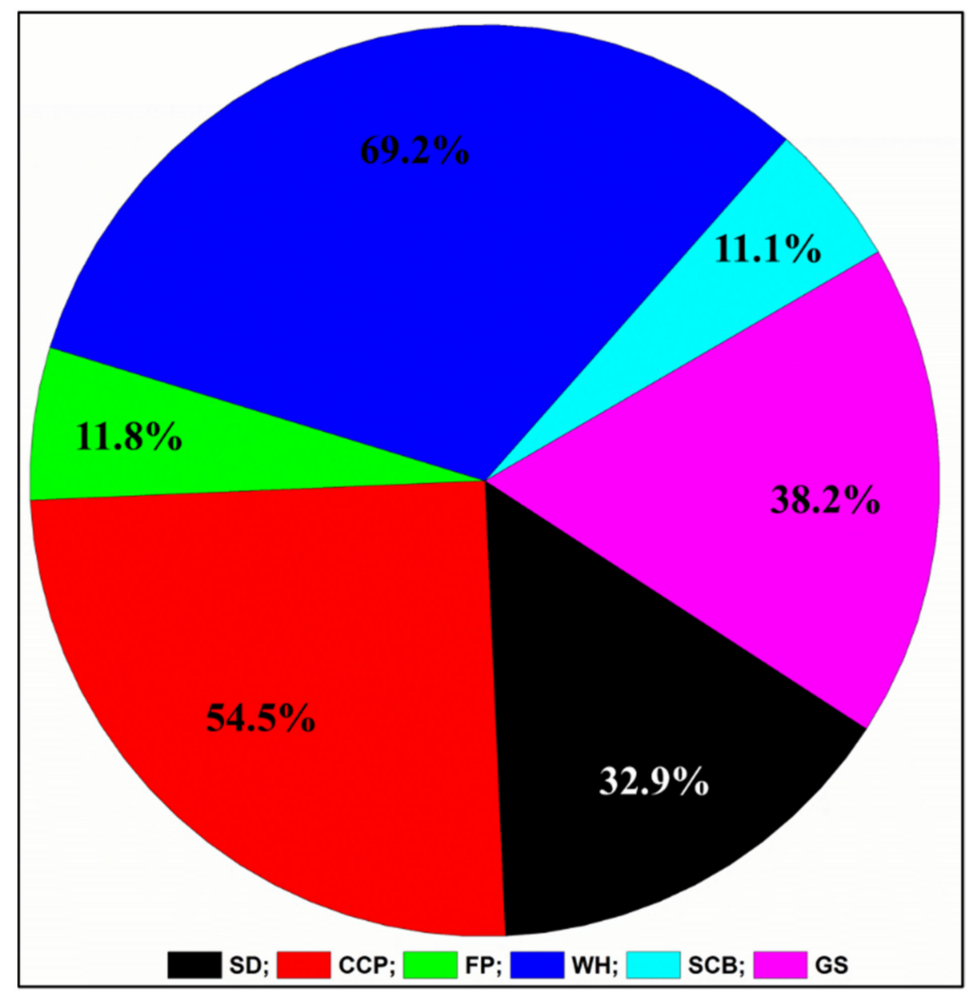

Figure 6. Percent (\%) substrate degradation achieved with various agro-wastes by B. altitudinis RSP75. SD: sawdust; CCP: corn cob powder; FP: filter paper; WH: wheat husk; SCB: sugarcane bagasse; GS: grass straw.

\subsection{Scanning Electron Microscopy and Characterization of the Hydrolyzed Substrates}

The characterization of hydrolyzed substrates is imperative for a comprehensive understanding of the substrate degradation by bacteria. To this end, the effects of B. altitudinis RSP75 on agro-wastes and FP as substrates were determined by FESEM and FTIR techniques. The FESEM-based visualization and comparison of the surface topographies between control and treated agro-wastes showed that surface morphologies were marked by discernible structural changes (Figure 7). The control substrates had a smooth texture while the surfaces of treated agro-wastes were rough and porous. In the case of the tested substrates, the bacterial cells were found to make tunnels and pores, exposing the inner fibers of the cellulosic biomass, while in WH, B. altitudinis RSP75 catalyzed superficial hydrolysis of the biomass. Moreover, B. altitudinis RSP75 released microfibers from the long chains of cellulose, as can be seen in the micrographs of all tested substrates (Figure $7 \mathrm{~B}, \mathrm{D}, \mathrm{F}, \mathrm{H})$. The disruption of LC biomass was also evident as high volumes of hydrolyzed biomass were found to accumulate on the surfaces of treated substrates. The rupturing of the substrates and adhesion of the bacterial cells further demonstrated the utilization of the agro-wastes as carbon or energy sources by the bacterium. 

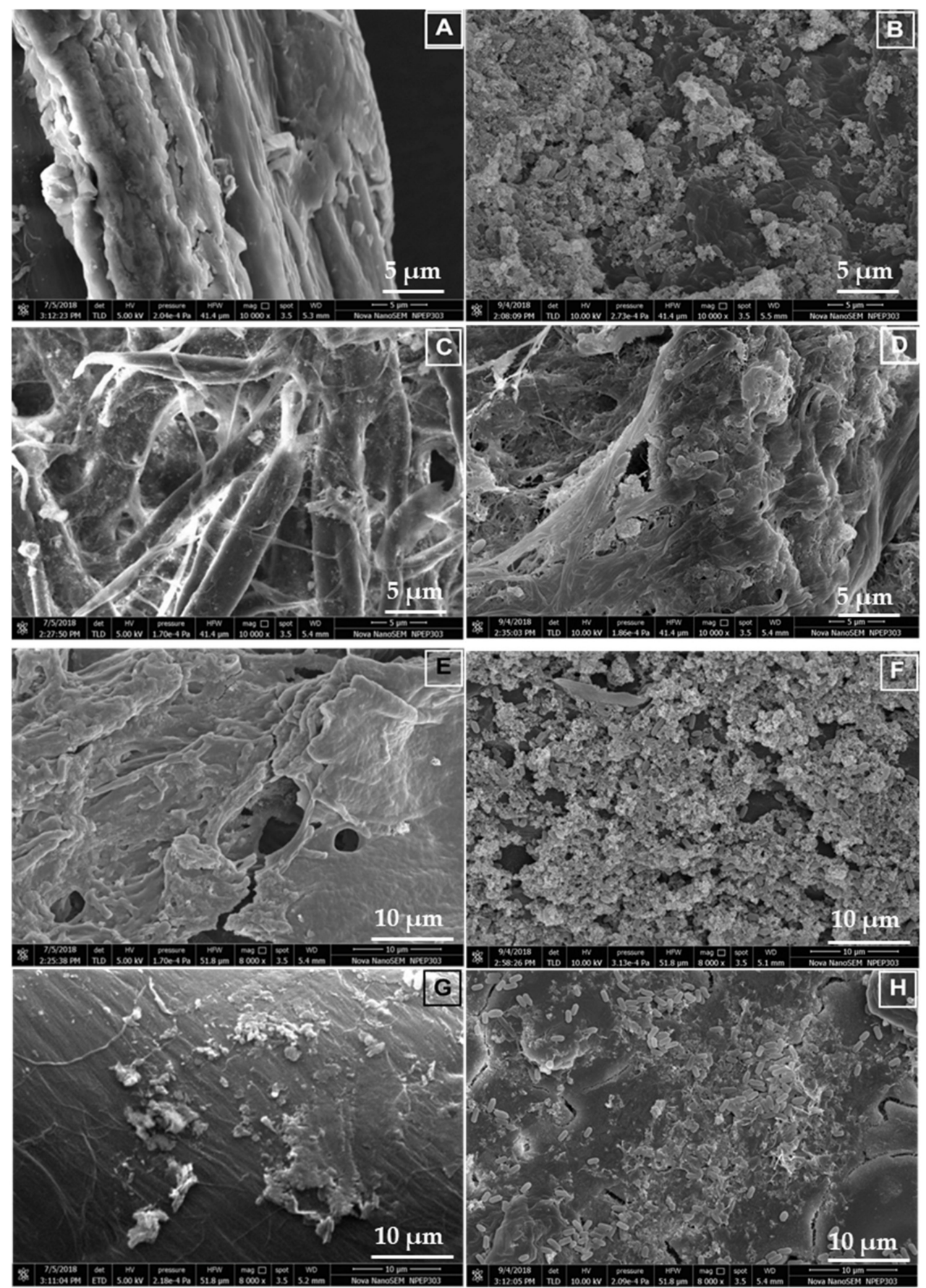

Figure 7. Hydrolysis of agro-wastes and FP used as substrates for the production of cellulases by B. altitudinis RSP75 after 8 days of incubation in BMS media. Field emission scanning electron micrograph of untreated corncob powder (A), treated corncob powder (B), untreated filter paper (C), treated filter paper $(\mathbf{D})$, untreated sugarcane bagasse $(\mathbf{E})$, treated sugarcane bagasse $(\mathbf{F})$, untreated (G) and treated wheat husk (H).

The FTIR analysis showed subtle alteration of the functional groups due to enzymatic hydrolysis. The FTIR spectral profiles of untreated and treated FP showed marked differences in the areas that represent cellulose (Figure 8). A band at $2920 \mathrm{~cm}^{-1}$ is a characteristic of the methyl group $\left(\mathrm{OCH}_{3}\right)$ present in cellulose. The intense absorption bands from 890 to $1750 \mathrm{~cm}^{-1}$ could be assigned to crystalline and amorphous cellulose contents of the FP. The IR band at $1164 \mathrm{~cm}^{-1}$ attributed to C-O-C represents an asymmetric stretching. The noteworthy difference between untreated and treated FP was a change in the intensity of 
the absorption band at $1735 \mathrm{~cm}^{-1}$. The hydrolysis of the FP was further supported by the decrease in the intensity of bands at 1247 and $1425 \mathrm{~cm}^{-1}$ which represent the stretching of the C-O bonds in cellulose. The reduction in the absorption bands at 1325 and $1375 \mathrm{~cm}^{-1}$ also indicated the degradation of the crystalline cellulose caused by B. altitudinis RSP75. The deformation of $\mathrm{C}-\mathrm{H}$ and stretching of the $\mathrm{C}=\mathrm{O}$ bonds at 1425 and $1630 \mathrm{~cm}^{-1}$, respectively, elucidate the reduction in band intensities, depicting cellulose hydrolysis. Lastly, the intensification of the bands at $898 \mathrm{~cm}^{-1}$ is indicative of the degradation of amorphous contents in cellulosic materials. All these structural alterations infer the utilization of FP as a carbon source for metabolite (reducing sugar) production by the bacterium.

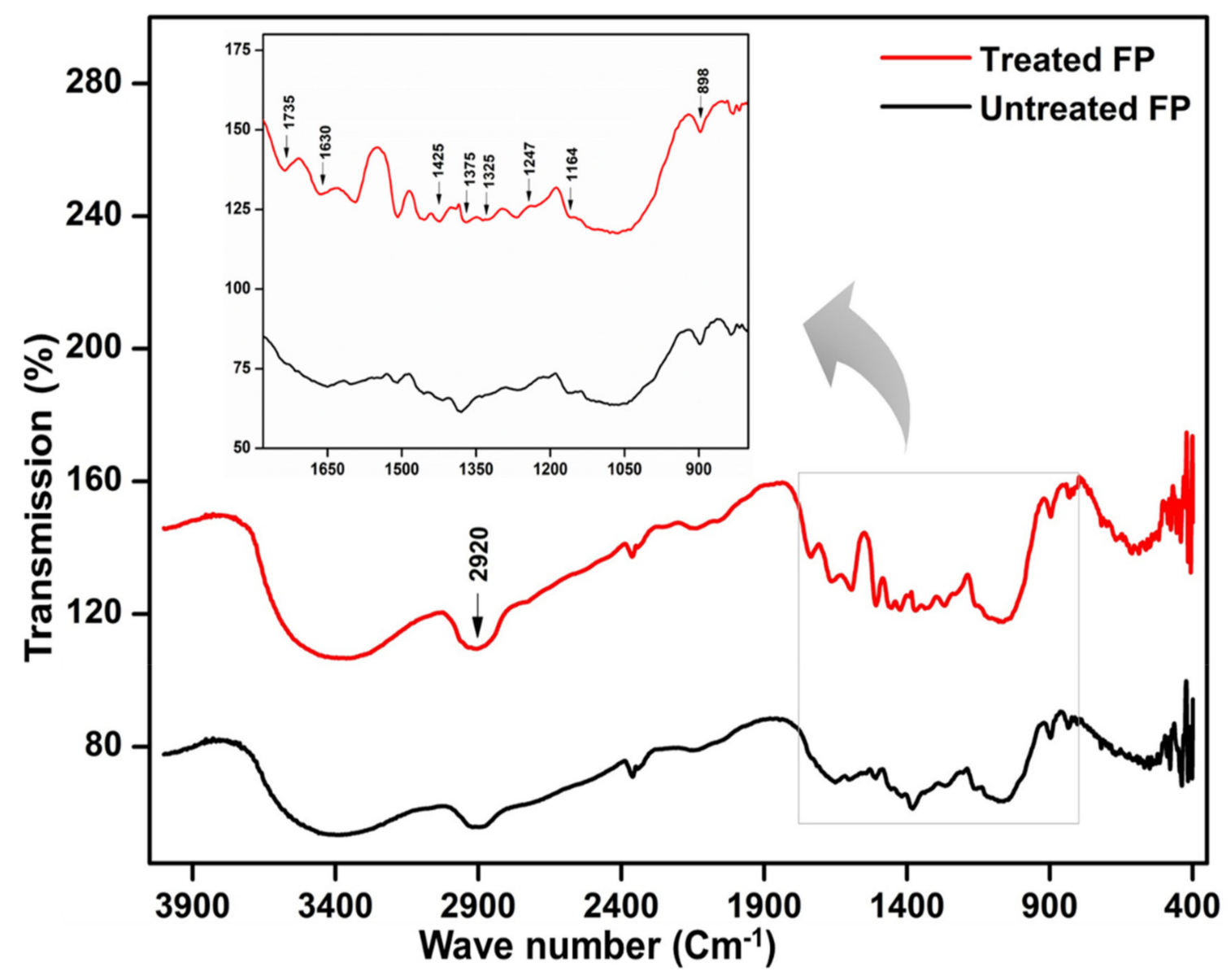

Figure 8. FTIR analyses of filter paper before and after hydrolysis by the bacterium B. altitudinis RSP75. The FP was used as the sole source of carbon for the growth of the bacterium.

\subsection{GS-MS Analysis}

To propose the possible mechanism of cellulose bioconversion by the gut bacterium B. altitudinis RSP75, the metabolic products were detected and identified by mass spectrometry. The GS-MS analysis identified the compounds released during hydrolysis and fermentation of LC wastes. The total ion chromatographic (TIC) profile of the compounds derived from hydrolyzed biomass in fermentation culture is shown in Figure S4, whereas the identities of the obtained peaks are presented in Table 2. The TIC profile of the hydrolysate displayed a large number of peaks, indicating the release of many low-molecularweight compounds from the agro-waste due to cellulolytic activities of B. altitudinis RSP75. The low-molecular-weight compounds, such as ethanoic acid, methane carboxylic acid, acetasol, methyl ethanoate, acetone alcohol, methyl ester, and pyruvic acid, were detected in the culture broth. The most important peaks elucidating the fermentation were assigned to carbon dioxide and acetate, showing a retention time (RT) of 1.490 and 2.025, respec- 
tively. Ethanol is usually known to show a peak from $m / z=41$ to 45 which is quite clear in the mass spectrum of the hydrolyzed broth due to co-culturing of B. altitudinis RSP75 with $S$. cerevisiae. The mass peak at $29 \mathrm{~m} / z$ represented the presence of the acetaldehyde compound. The peaks corresponding to 2-propanone (acetol) and propanoic acid (acetic anhydride) showed RTs of 2.275 and 3.115, respectively. Carbon dioxide is known to contribute most ions to mass number $m / z=44$ which was also observed in the present study. Being the intermediate metabolites of cellulose fermentation, propionate and methyl pyruvate signpost the breakdown of cellulose by the bacterium. Based on our investigation and the FTIR and GC-MS analyses, together with enzyme assays, a schematic pathway was proposed for the hydrolysis mechanism of B. altitudinis RSP75 which is elucidated in the discussion section.

Table 2. Mass spectrometry-based identification of the fermentation products generated during the co-culture of B. altitudinis RSP75 with Saccharomyces cerevisiae.

\begin{tabular}{ccccc}
\hline Peak No. & Compound Name & Area (\%) & Retention Index & Rt (min) \\
\hline 1 & Ethanol & 0.78 & 45 & 2.523 \\
2 & Carbon dioxide & 7.39 & 44 & 1.490 \\
3 & Acetic acid & 18.31 & 576 & 2.025 \\
4 & Acetone alcohol & 14.57 & 698 & 2.275 \\
5 & Acetyldehyde & 6.00 & 29 & 3.115 \\
6 & 2-Propanone & 1.09 & 698 & 2.472 \\
\hline
\end{tabular}

\section{Discussion}

The process of bioprospection leads to the discovery of promising and potential microbes for industrial-scale biomass conversion. In this context, the physiologically diverse gut systems of insects represent unique niches to prospect for bacteria that can be harvested for bioengineering and consolidated bioprocessing. In recent years, insect gut systems have been proven as useful resources for enzymes with various industrial applications. Among insects, termites have been the primary focus for scientists to isolate LC-degrading gut bacteria [44]. Thus, the present study represents an additional group of insects that can be considered for bioprospection as they efficiently digest LC [45]. Despite being a well-known model system for multidimensional research in food safety and molecular sciences [46], currently little is known about the LC-degrading bacteria in the gut system of the tenebrionid beetle T. castaneum. To this end, the present study explored the cellulose-degrading bacteria from the gut system of T. castaneum and suggests it as a potential reservoir for lignocellulase-encoding proteins. Being a reliable, rapid, easy, and economic technique, MALDI-TOF mass spectrometry is commonly applied for the identification of Gram-positive bacteria [47]. To date, a number of cellulolytic bacteria have been identified using MALDI-TOF analyses [48,49]. In the present study, MALDI-TOF analysis indicated the presence of Bacillus, Citrobacter, Kluyvera, Escherichia, Enterococcus, Achromobacter, etc. in the gut of the beetle. Many researchers have described that Enterococcus, Escherichia, Kluyvera, and Citrobacter spp. are involved in a variety of functions in insects [50,51]. It has been established that these gut microbes play a significant part in the defense as well as nutrition of the host insects [52]. In particular, the majority of the Firmicutes that inhabit the gut systems of insects are mainly involved in carbohydrate depolymerization and nitrogen metabolism [51,53,54]. Likewise, the gut bacteria of $T$. castaneum might help the host in the digestion of wheat bran which is predominantly rich in dietary fibers such as xylans, cellulose, lignin, galactan, and fructans [18].

To characterize the CMCase activity of the isolated strains, different experimental assays were performed by using plate-based as well as analytical methods. The results of these experiments revealed that not all bacteria can grow and degrade $\mathrm{MC}$, however, a few strains of Citrobacter species and B. altitudinis RSP7 showed conspicuous CMCase activities. However, low, or the absence of, cellulolytic activity in some isolates suggested 
their primary functionalities other than carbohydrate digestion within the insect gut [55]. Of the 15 bacteria isolated in the present study, B. altitudinis RSP75 showed a relatively higher potential to degrade cellulose which was also evident from the downstream testing assays. The cellulose hydrolytic ratio and zone of CMC clearance by B. altitudinis RSP75 was much larger than the clearance zone by bacteria previously isolated from the larvae of Dendroctonus armandi [56].

To date, members of the genus Bacillus have been identified in many species of insects, such as scarab beetles, such as Holotrichia parallela [57], D. armandi [56], moths like Diatrea sacharalis [55], termite, C. formosanus [23], and snails [29,30,58], which are mostly cellulosedigesting animals [59-62]. However, to the best of our knowledge, isolation of B. altitudinis from an insect has not been reported previously, although its presence has been established in fish gut [63]. In this regard, the present investigation is the first study to report the presence of $B$. altitudinis strains in insect gut systems. Furthermore, the cellulolytic repertoire of $B$. altitudinis has not been characterized on agricultural wastes despite a few reports that focused on process optimization using simulations [63] but different isolation sources (Table S1). Bacillus altitudinis RSP75 is a spore-forming, white-colored, rod-shaped, Grampositive, aerobic, and mesophilic bacterium. The biochemical characteristics of B. altitudinis RSP75 were in line with earlier reports [64,65]. From the biochemical characterization, it is evident that $B$. altitudinis RSP75 can utilize many polysaccharide components of plant cell walls such as cellulose, xylan, starch, and mannose. Our observations are in congruence with those of Vettath and coworkers who stated that many genes (875 out of 3820 protein-coding genes) in B. altitudinis encode for carbohydrate and protein metabolism [66]. Since mannan constitutes an important component of prebiotics for animal husbandry and nutritional supplements [67], B. altitudinis RSP75 could prove to be a promising candidate for mannan oligosaccharide-based dietary supplements of dairy and feedstock. Bacillus altitudinis RSP75 also showed a growth pattern similar to B. megaterium S3, showing slow and extended growth on CMC media [68] due to a metabolic shift to use cellulose as a carbon source. One of the peculiarities of B. altitudinis RSP75 is the ability to grow under acidic $\mathrm{pH}$ because relatively few bacterial species are known to tolerate acidic conditions, particularly in nature [69]. The acidophilic nature of B. altitudinis RSP75 signifies that its enzymes are likely to function well at acidic $\mathrm{pHs}$ prevailing in biomass conversion processes. The acidophilic enzymes have a variety of applications such as in feedstock, baking, and biofuel industries [70].

The enzymatic profile and substrate degradation revealed that B. altitudinis RSP75 can effectively degrade agro-residue-based substrates such as GS, WH, and SCB, showing significant production of cellulolytic and hemicellulolytic enzymes responsible for LC degradation. This, in other words, signifies that B. altitudinis RSP75 could be employed to valorize the waste sector into a green useful materials sector for the production of high-value biochemicals. The significant observation of the present study is the secretion of complex LC-hydrolyzing enzymes such as xylanase, $\beta$-glucosidases, endoglucanase, and glucoamylase. The good xylanase, $\beta$-glucosidases, and glucoamylase activities observed in B. altitudinis RSP75 demonstrate positive corroboration of the xylan- and starch-rich diet of the beetle (host). Since starch comprises $16 \%$ of the dry weight of wheat bran [71], $B$. altitudinis RSP75 may prove very useful for its waste disposal management and subsequent bioconversion. However, $\beta$-glucosidase activities of B. altitudinis RSP75 were lower than the activity of B. altitudinis YC-9 (Table 3). The observed difference could have been due to the different assay conditions used. In addition, spring silt as a different source of isolation for B. altitudinis YC-9 could have contributed to the observed differences in enzyme activity [65]. 
Table 3. The comparison of the enzyme activity of B. altitudinis RSP75 with some previously reported aerobic Gram-positive cellulose-degrading bacterial strains.

\begin{tabular}{|c|c|c|c|c|c|}
\hline Bacteria & $\begin{array}{c}\text { NCBI } \\
\text { Accession }\end{array}$ & $\begin{array}{c}\text { Substrate } \\
\text { Clearance Zone } \\
(\mathrm{mm})\end{array}$ & $\begin{array}{l}\text { Cellulase Activity } \\
\text { IU/mL (or mg) } \\
\text { Extract }\end{array}$ & $\begin{array}{l}\text { Xylanase Activity } \\
\text { IU/mL Extract }\end{array}$ & Reference \\
\hline B. altitudinis RSP75 & MW559543 & 28 & $47.1 \pm 3$ & $60.2 \pm 2$ & This study \\
\hline B. subtilis $1 \mathrm{AJ} 3$ & MG062801 & 19 & 0.04 & ND & \\
\hline B. methylotrophicus 1EJ7 & MG062824 & 19 & 0.025 & ND & [72] \\
\hline Bacillus sp. JMP-A & HM776393 & 11 & 27.10 & ND & [73] \\
\hline Bacillus sp. NT4 & GU458276 & ND & $\sim 2.5$ & ND & [74] \\
\hline Bacillus megaterium RU4 & NA & 14.5 & ND & ND & [75] \\
\hline Paenibacillus sp. C1 & NA & NA & 0.9 & ND & [76] \\
\hline Bacillus anthracis AR426 & LN829572 & ND & $0.36 \pm 0.04$ & ND & \\
\hline Cohnella formosensis AR92 & FJ976043 & ND & $0.15 \pm 0.03$ & ND & [77] \\
\hline B. tequilensis $\mathrm{G} 9$ & KR866144 & 25 & 598.07 & 74.02 & [29] \\
\hline Bacillus megaterium SCMC89 & KF358455 & $>8$ & ND & ND & [78] \\
\hline Exiguobacterium marinum TN25 & NA & 16 & ND & ND & [79] \\
\hline B. subtilis BY-2 & KC414931 & NA & 1.52 & ND & [80] \\
\hline Bacillus amyloliquefaciens SS35 & AB679994 & NA & 0.079 & ND & [81] \\
\hline Cellulomonas sp. & NA & NA & 0.0336 & ND & \\
\hline Bacillus sp. & NA & NA & 0.0196 & ND & [82] \\
\hline Micrococcus sp. & NA & NA & 0.0152 & ND & \\
\hline
\end{tabular}

ND, not detected; NA, not available.

The topographical changes in tested substrates including FP and WH are important considerations that indicate disruption of the polymer due to bacteria, signifying the secretion of hydrolytic enzymes [83]. The FESEM imaging of the treated CCP, SCB, WH, and FP exhibited cracking and delamination of substrates. Similar observations were also made by many researchers in the case of wood composites treated with bacteria and fungi $[84,85]$. These observations also corroborated previous reports where authors stated cracking and loosening of rice straw due to bacterial treatment [86]. The authors further stated that microbes initially devour the outer polymers of the substrates, releasing toxic metabolites in the form of esterases or organic acids. The released compounds damage the surfaces of the polymer, hence exposing inner chains of the composite which are susceptible to enzymatic action, thereby accelerating degradation [87].

Due to structural complexity, the LC compounds are recalcitrant to enzymatic hydrolysis [88]. The substrate degradation potential (32-69.2\%) of B. altitudinis RSP75 was much higher than the degradation capacity (10.7\%) of many previously reported Bacillus [89] and Klebsiella species [12]. Among the tested agro-wastes, the maximum degradation was achieved with WH followed by CCP and GS. WH is a renewable and rich source of hemicellulose contents, including xylans, galactan, and fructans, along with some minerals [90]. Since it is abundantly available, its bioconversion could prove a vital and sustainable source of energy alongside feedstock for animals [91]. The substrate degradation ratio and FESEM results were in congruence with the FTIR spectral analysis. The prominent changes observed were the removal of the bands representing cellulose at 1630 and $1735 \mathrm{~cm}^{-1}$ corresponding to the $\mathrm{C}=\mathrm{O}$ stretching of the aldehyde groups of the carbon source [92-95]. The FTIR observations were also in agreement with many earlier studies [96,97]. The absorption peaks at 1320 and $1425 \mathrm{~cm}^{-1}$ were assigned to the symmetric $\mathrm{CH}_{2}$ wagging and bending while the absorption band of $\sim 1375 \mathrm{~cm}^{-1}$ represented bending of C-H bonds [98,99]. The absence of these bands in the treated substrate congruently indicated $B$. altitudinis RSP75-mediated hydrolysis.

During co-culture, the bacterium, B. altitudinis RSP75 provided sugars to the yeast for which it primarily attacked the $\beta-1,4$ linkage of the cellulose fibrils, releasing either the short chains of cellulose or terminal disaccharide units, i.e., cellobiose (Figure 9). The released cellobiose units are hydrolyzed further by cellobiase into a six-carbon sugar, glucose. Similarly, hemicellulose, where xylan occupies the major part, is acted upon by 
different endoxylanases, releasing short stretches of xylan which are then broken down by exoxylanases into five-carbon sugars. These five- and six-carbon sugars are ingested by the yeast as well as bacterial cells and metabolized primarily in the Embden-MeyerhofParnas pathway. The two units of the pyruvate generated from each sugar molecule are then converted into acetaldehyde and subsequently oxidized into $\mathrm{CO}_{2}$ and ethanol in the mitochondria via anaerobic fermentation by the yeast. The majority of these chemical compounds were identified in the culture broth in terms of the mass spectra and $m / z$ values (Table 2). The mass spectra of the metabolites revealed major peaks with retention times of 1.4, 2.05, 2.27, 3.11, 4.88, and $8.15 \mathrm{~min}$. Moreover, the GS-MS analysis showed three characteristic peaks for ethanol, carbon dioxide, and acetaldehyde. The peak with a molecular mass of 45 and retention time of 2.523 is characteristic of ethanol [43]. The peaks at 29 and 44 signified the production of chemical compounds such as acetaldehyde and $\mathrm{CO}_{2}$, respectively [100]. To date, significant progress has been made for ethanol fermentation from LC by using co-cultivation of microorganisms. Recently, Harish and colleagues reported $0.41 \mathrm{~g} / \mathrm{g}$ of ethanol produced from banana waste using co-culture of $C$. thermocellum and $C$. thermosaccharolyticum. The authors also mentioned that cocultivation was more effective for cellulose hydrolysis and reducing sugar production and bioconversion [101]. Similar to previous reports, we observed that co-culturing of B. altitudinis RSP75 and yeast significantly improves the rate of LC bioconversion and ethanol yield within a short duration of fermentation [102,103].

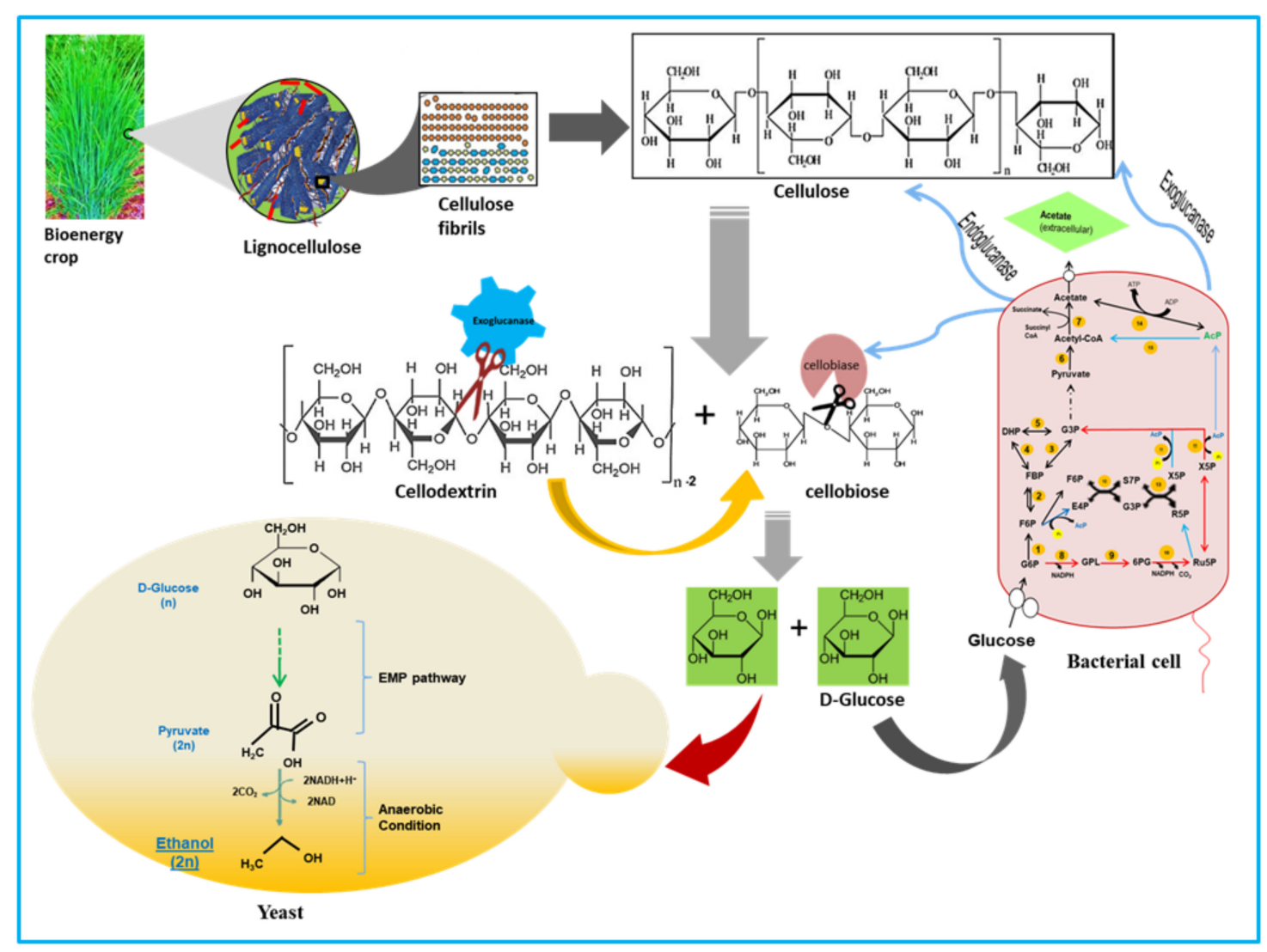

Figure 9. Predicted mechanism/pathways used by B. altitudinis RSP75 for the metabolism of cellulose with synergism with yeast strain for ethanol production. G6P: glucose-6-phosphate; GPL: 6-phospho glucono 1, 5 lactone; 6PG: 6-phosphogluconate; Ru5P: riulose-5-phosphate; X5p: xylulose-5-phosphate; R5P: ribose-5-phosphate; S7P: sedoheptulose7-phosphate; G3P: glyceraldehyde-3-phosphate; F6P: fructose-6-phosphate; E4P: erythrose-4-phosphate; F6P: fructose-6phosphate; FBP: fructose-1,6-bisphosphate; DHP: dihydroxyacetone phosphate; AcP: acetyl phosphate. The numbers in yellow circles indicate enzymes, 1: glucokinase; 2: phosphoglucokinase; 3 and 4: aldolase; 5 : isomerase; 6: pyruvate dehydrogenase complex; 7: pyruvate oxidase; 8 and 9: glucose-6-phosphate dehydrogenase; 10: 6-phosphogluconate dehydrogenase; 11: bifunctional phosphor ketolase; 12: transaldolase; 13: transketolase; 14: acetate kinase; 15: phosphotransacetylase. 
All of the above characteristics demonstrate the potential lignocellulolytic repertoire of B. altitudinis RSP75, and therefore encourage its further characterization for LC bioconversion. The noteworthy contribution of our study is the isolation of the B. altitudinis RSP75 strain from the gut system of $T$. castaneum bearing significant lignocellulolytic potentials. Isolation of B. altitudinis RSP75 from T. castaneum and its subsequent characterization also suggests its supplementary role in the host in cellulose digestion. Whether B. altitudinis RSP75 represents a valuable metabolic collaborator with $T$. castaneum, enhancing its ability to dwell on cellulosic plant matter, warrants further consideration. Moreover, further studies are needed to elucidate if these bacteria are indeed more efficient in degrading cellulose by cloning individual cellulase-encoding genes. Nevertheless, the obtained results are encouraging and suggest further investigation of the efficiency and cellulolytic activity of cellulases and hemicellulases from the potential strain B. altitudinis RSP75 for possible application in bioconversion of $\mathrm{WH}$ and $\mathrm{SCB}$ into 2 nd generation bioethanol or other processes.

\section{Conclusions}

The present study demonstrated the gut of T. castaneum to be a unique and potential resource for the bioprospection of efficient cellulose-degrading bacteria. The potential isolate identified as B. altitudinis RSP75 produced many lignocellulose-hydrolyzing enzymes that could be utilized to break down agro-wastes into readily usable commodity chemicals. The substrate degradation efficiency of B. altitudinis RSP75 on agricultural wastes depicted its intricate enzyme activity, creating pores and causing deconstruction of the cellulose. The FESEM imaging of the hydrolyzed biomass together with enzyme assays revealed the inherent capacity of B. altitudinis RSP75 to valorize LC bioconversion, thereby warranting its further characterization for possible industrial applications. Similarly, FTIR spectroscopic analysis of the FP suggested the elimination of bands that represent cellulose contents. Further, the mass spectrometric analysis revealed compatibility of the bacterium with a fermentation-efficient yeast strain which also suggests its industrial significance towards biofuel production.

Supplementary Materials: The following are available online at https:/ /www.mdpi.com/article/10 .3390/microorganisms9091952/s1, Figure S1: Plate based assay for screening the cellulose degrading activity of the isolated bacteria. (A) Isolates patched and grown on BMS agar plates showing zones of CMC clearance around the bacterial colonies indicative of cellulolytic activity. (B) Percentage $(\%)$ of isolates depicting various hydrolytic capacity $(\mathrm{HC})$ ratios on BMS agar media containing $0.5 \% \mathrm{CMC}$ as carbon source.; Figure S2: A dot plot alignment of the $16 \mathrm{~S}$ rDNA gene sequence from B. altitudinis RSP75 against the same gene sequence of its closest NCBI relative $B$. altitudinis (accession no. MN746197); Figure S3: Enzymatic profile of the B. altitudinis RSP75 on various commercial and agro-wastes used as substrates over the period of incubation. (a) Endoglucanase; (b) Cellobiase; (c) Xylanase, and (d) Glucoamylase activities. Values are means \pm SD of three or more independent replicates. GS: grass straw; CCP: corn cob powder; SD: sawdust; FP: Filter paper; WH: Wheat husk; SCB: Sugarcane bagasse; Figure S4: The gas chromatography-Mass Spectrometry (GC-MS) analysis for identification of metabolites co-culturing the B. altitudinis RSP7 with Sacharomycescerevisae for fermentation of reducing sugars produced from wheat husk. Mass spectra of the metabolites produced from fermentation of sugars in culture media A), Chromatogram of the fermentation products obtained from the culture broth B); Table S1: Reports on the isolation of B. altitudinis strains from various environments/sources and their characteristics.

Author Contributions: Conceptualization, M.A.D. and N.P.D.; Methodology, M.A.D., P.R. and K.D.P.; Software, K.D.P. and K.U.; Validation, P.R., R.X. and K.D.P.; Formal analysis, M.A.D. and K.D.P.; Investigation, N.P.D.; Resources, R.S.P. and J.S.; Data curation, K.D.P., R.X. and P.R.; Writing-original draft preparation, M.A.D. and N.P.D.; writing-review, and editing, R.S.P. and J.S.; Visualization, M.A.D., K.U. and K.D.P.; Supervision, R.S.P., K.D.P., R.X. and J.S.; Project administration, K.D.P.; Funding acquisition, R.S.P., K.D.P. and J.S. All authors have read and agreed to the published version of the manuscript. 
Funding: This study was supported by the grants received from the National Natural Science Foundation of China $(31900367,31772529)$ and Jiangsu University, China (5363000606, 10JDG127). N.P.D. is grateful to the Council of Scientific and Industrial Research (CSIR), Govt. of India for providing a senior research fellowship. R.S.P. acknowledges S.P. Pune University, Pune for the grants received under DRDP, UGC-CAS III, and DST-PURSE schemes. K.D.P. acknowledges the DBT-BUILDER-SUK program sanctioned to Shivaji University, Kolhapur, India. The funders had no role in study design, data collection, analyses, decision to publish, or preparation of the manuscript.

Institutional Review Board Statement: Not applicable.

Informed Consent Statement: Not applicable.

Data Availability Statement: All the data sets generated for this research are included in the manuscript or Supplementary Files.

Acknowledgments: We thank Hemant V. Ghate for the identification of beetle species and Pandey S. for assistance provided during the initial experimentation.

Conflicts of Interest: The authors declare that no competing interests exist concerning the research, authorship, and/or publication of this article.

\section{References}

1. Zhang, K.; Pei, Z.; Wang, D. Organic solvent pretreatment of lignocellulosic biomass for biofuels and biochemicals: A review. Bioresour. Technol. 2016, 199, 21-33. [CrossRef]

2. Väisänen, T.; Haapala, A.; Lappalainen, R.; Tomppo, L. Utilization of agricultural and forest industry waste and residues in natural fiber-polymer composites: A review. Waste Manag. 2016, 54, 62-73. [CrossRef] [PubMed]

3. Maurya, D.P.; Singla, A.; Negi, S. An overview of key pretreatment processes for biological conversion of lignocellulosic biomass to bioethanol. 3 Biotech 2015, 5, 597-609. [CrossRef] [PubMed]

4. Dashtban, M.; Schraft, H.; Qin, W. Fungal bioconversion of lignocellulosic residues; opportunities and perspectives. Int. J. Boil. 2009, 5, 578-595. [CrossRef] [PubMed]

5. Maki, M.; Leung, K.T.; Qin, W. The prospects of cellulase-producing bacteria for the bioconversion of lignocellulosic biomass. Int. J. Biol. 2009, 5, 500-516. [CrossRef]

6. Kalyani, D.; Lee, K.M.; Kim, T.S.; Li, J.; Dhiman, S.S.; Kang, Y.C.; Lee, J.K. Microbial consortia for saccharification of woody biomass and ethanol fermentation. Fuel 2013, 107, 815-822. [CrossRef]

7. Sun, J.Z.; Scharf, M.E. Exploring and integrating cellulolytic systems of insects to advance biofuel technology. Insect Sci. 2010, 17, 163-165. [CrossRef]

8. Shi, W.; Ding, S.Y.; Yuan, J.S. Comparison of insect gut cellulase and xylanase activity across different insect species with distinct food sources. Bioenergy Res. 2011, 4, 1-10. [CrossRef]

9. Watanabe, H.; Tokuda, G. Animal cellulases. Cell. Mol. Life Sci. 2001, 58, 1167-1178. [CrossRef]

10. Sun, J.; Ding, S.Y.; Doran-Peterson, J. Biological Conversion of Biomass for Fuels and Chemicals: Exploration from Natural Utilization Systems, 1st ed.; Royal Society of Chemistry: Cambridge, UK, 2014; pp. 1-427.

11. Xie, S.X.; Syrenne, R.; Sun, S.; Yuan, J.S. Exploration of natural biomass utilization systems (NBUS) for advanced biofuel-from systems biology to synthetic design. Curr. Opin. Biotechnol. 2014, 27, 195-203. [CrossRef]

12. Dar, M.A.; Shaikh, A.A.; Pawar, K.D.; Pandit, R.S. Exploring the gut of Helicoverpa armigera for cellulose degrading bacteria and evaluation of a potential strain for lignocellulosic biomass deconstruction. Proc. Biochem. 2018, 73, 142-153. [CrossRef]

13. Adegboye, M.F.; Ojuederie, O.B.; Talia, P.M.; Babalol, O.O. Bioprospecting of microbial strains for biofuel production: Metabolic engineering, applications, and challenges. Biotechnol. Biofuels 2021, 14, 5. [CrossRef]

14. Smith, E.H.; Whitman, R.C. Stored product pests. In Field Guide to Structural Pests; National Pest Management Association: Fairfax, VA, USA, 2007; pp. 1-764.

15. Ridley, A.W.; Hereward, J.P.; Daglish, G.J.; Raghu, S.; Collins, P.J.; Walter, G.H. The spatiotemporal dynamics of Tribolium castaneum (Herbst): Adult flight and gene flow. Mol. Ecol. 2011, 20, 1635-1646. [CrossRef] [PubMed]

16. Buxton, T.; Owusu, E.O.; Kim, C.S. Bioactivity of cardanol against the rust red flour beetle, Tribolium castaneum (Coleoptera: Tenebrionidae). Int. J. Trop. Insect Sci. 2018, 38, 353-361. [CrossRef]

17. Padín, S.; Dal Bello, G.; Fabrizio, M. Grain loss caused by Tribolium castaneum, Sitophilus oryzae and Acanthoscelides obtectus in stored durum wheat and beans treated with Beauveria bassiana. J. Stored Prod. Res. 2002, 38, 69-74. [CrossRef]

18. DeBrier, N.; Hemdane, S.; Dornez, E.; Gomand, S.V.; Delcour, J.A.; Courtin, C.M. Structure, chemical composition and enzymatic activities of pearlings and bran obtained from pearled wheat (Triticum aestivum L.) by roller milling. J. Cereal Sci. 2015, 62, 66. [CrossRef]

19. Willis, J.D.; Grant, J.N.; Mazarei, M.; Kline, L.M.; Rempe, C.S.; Collins, A.G.; Turner, G.B.; Decker, S.R.; Sykes, R.W.; Davis, M.F.; et al. The TcEG1 beetle (Tribolium castaneum) cellulase produced in transgenic switchgrass is active at alkaline $\mathrm{pH}$ and auto-hydrolyzes biomass for increased cellobiose release. Biotechnol. Biofuels 2017, 10, 230. [CrossRef] 
20. Willis, J.D.; Oppert, B.; Oppert, C.; Klingeman, W.E.; Jurat-Fuentes, J.L. Identification, cloning, and expression of a GHF9 cellulase from Tribolium castaneum (Coleoptera: Tenebrionidae). J. Insect Physiol. 2011, 57, 300-306. [CrossRef]

21. Shirley, D.; Oppert, C.; Reynolds, T.B.; Miracle, B.; Oppert, B.; Klingeman, W.E.; Jurat-Fuentes, J.L. Expression of an endoglucanase from Tribolium castaneum (TcEG1) in Saccharomyces cerevisiae. Insect Sci. 2014, 21, 609-618. [CrossRef]

22. Rehman, F.; Aslam, M.; Tariq, M.I.; Shaheen, A.; Sami, A.J.; Naveed, N.H.; Batoo, A.I. Isolation of cellulolytic activities from Tribolium castaneum (red flour beetle). Afr. J. Biotechnol. 2009, 8, 6710-6715. [CrossRef]

23. Geng, A.; Cheng, Y.; Wang, Y.; Zhu, D.; Le, Y.; Wu, J.; Xie, R.; Yuan, J.S.; Sun, J. Transcriptome analysis of the digestive system of a wood-feeding termite (Coptotermes formosanus) revealed a unique mechanism for effective biomass degradation. Biotechnol. Biofuels 2018, 11, 24. [CrossRef] [PubMed]

24. Tokuda, G.; Watanabe, H.; Matsumoto, T.; Noda, H. Cellulose digestion in the wood-eating higher termite, Nasutitermes takasagoensis (shiraki): Distribution of cellulases and properties of endo- $\beta-1,4-$ gIucanase. Zool. Sci. 1997, 14, 83-93. [CrossRef] [PubMed]

25. Dar, M.A.; Shaikh, A.F.; Pawar, K.D.; Xie, R.R.; Sun, J.Z.; Kanasamy, S.; Pandit, R.S. Evaluation of cellulose degrading bacteria isolated from the gut-system of cotton bollworm, Helicoverpa armigera and their potential values in biomass conversion. Peer 2021, 9, e11254. [CrossRef]

26. Shil, R.K.; Mojumder, S.; Sadida, F.F.; Uddin, M.; Sikdar, D. Isolation and identification of cellulolytic bacteria from the gut of three phytophagus insect species. Braz. Arch. Biol. Technol. 2014, 57, 927-932. [CrossRef]

27. Luo, C.; Li, Y.; Liao, H.; Yang, Y. De novo transcriptome assembly of the bamboo snout beetle, Cyrtotrachelus buqueti reveals ability to degrade lignocellulose of bamboo feedstock. Biotechnol. Biofuels 2018, 11, 292. [CrossRef]

28. Lemke, T.; Ulrich, S.; Egert, M.; Friedrich, M.W.; Brune, A. Physicochemical conditions and microbial activities in the highly alkaline gut of the humus-feeding larva of Pachnoda ephippiata (Coleoptera: Scarabaeidae). Appl. Environ. Microbial. 2003, 69, 6650-6658. [CrossRef]

29. Dar, M.A.; Pawar, K.D.; Pandit, R.S. Prospecting the gut fluid of giant African land snail, Achatina fulica for cellulose degrading bacteria. Int. Biodeterior. Biodegrad. 2018, 126, 103-111. [CrossRef]

30. Dar, M.A.; Pawar, K.D.; Jadhav, J.P.; Pandit, R.S. Isolation of cellulolytic bacteria from the gastro-intestinal tract of Achatina fulica (Gastropoda: Pulmonata) and their evaluation for cellulose biodegradation. Int. Biodeterior. Biodegrad. 2015, 98, 73-80. [CrossRef]

31. Good, N.E. The Flour Beetles of the Genus Tribolium; USDA Report; United States Department of Agriculture: Washington, DC, USA, 1936; Volume 498, pp. 1-58.

32. Kirkup, D. Lucid Professional Version 2.0: Tools for identification and diagnosis. Centre for Pest Information Technology \& Transfer. Ann. Bot. 2002, 89, 650-651. [CrossRef]

33. Schulthess, B.; Bloemberg, G.V.; Zbinden, R.; Böttger, E.C.; Hombach, M. Evaluation of the Bruker MALDI Biotyper for identification of gram-positive rods: Development of a diagnostic algorithm for the clinical laboratory. J. Clin. Microbiol. 2014, 52, 1089-1097. [CrossRef]

34. Weisburg, W.G.; Barns, S.M.; Pelletier, D.A.; Lane, D.J. 16 S ribosomal DNA amplification for phylogenetic study. J. Bacteriol. 1991, 173, 697-703. [CrossRef]

35. Kumar, S.; Stecher, G.; Li, M.; Knyaz, C.; Tamura, K. MEGA X: Molecular evolutionary genetics analysis across computing platforms. Mol. Biol. Evol. 2018, 35, 1547-1549. [CrossRef] [PubMed]

36. Rice, P.; Longden, I.; Bleasby, A. EMBOSS: The European molecular biology open software suite. Trends Genet. 2000, 16, 276-277. [CrossRef]

37. Gao, Z.; Hop, V.; Yen, D.; Ando, K.; Hiyamuta, S.; Kondo, R. The production of $\beta$-glucosidases by Fusarium proliferatum NBRC109045 isolated from Vietnamese forest. AMB Express 2012, 2, 49. [CrossRef] [PubMed]

38. Miller, G.L. Use of dinitrosalicylic acid reagent for determination of reducing sugar. Anal. Chem. 1959, 31, 426-428. [CrossRef]

39. Lowry, O.H.; Rosebrough, N.J.; Farri, A.L.; Randall, R.J. Protein measurement with the folin phenol reagent. J. Biol. Chem. 1951, 193, 265-275. [CrossRef]

40. Du, R.; Yan, J.; Li, S.; Zhang, L.; Zhang, S.; Li, J.; Zhao, G.; Qi, P. Cellulosic ethanol production by natural bacterial consortia is enhanced by Pseudoxanthomonas taiwanensis. Biotechnol. Biofuels 2015, 8, 1-10. [CrossRef]

41. Dar, M.A.; Pawar, K.D.; Rajput, B.P.; Rahi, P.; Pandit, R.S. Purification of a cellulase from cellulolytic gut bacterium, Bacillus tequilensis G9 and its evaluation for valorization of agro-wastes into added value byproducts. Biocatal. Agric. Biotechnol. 2019, 20, 101219. [CrossRef]

42. Galabova, D.; Tuleva, B.; Spasova, D. Permeabilization of Yerrowia lipolytica cells by Triton X-100. Enzym. Microb. Technol. 1996, 18, 18-22. [CrossRef]

43. Bagewadi, Z.K.; Mulla, S.I.; Ninnekar, H.Z. Purification and characterization of endob-1,4-D-glucanase from Trichoderma harzianumstrain HZN11 and its application in production of bioethanol from sweet sorghum bagasse. 3 Biotech 2016, 6, 101. [CrossRef]

44. Tsegaye, B.; Balomajumder, C.; Roy, P. Isolation and characterization of novel lignolytic, cellulolytic, and hemicellulolytic bacteria from wood-feed termite, Cyrptotermes brevis. Int. Microbiol. 2018, 22, 29-39. [CrossRef]

45. Bugg, T.D.; Ahmad, M.; Hardiman, E.M.; Singh, R. The emerging role for bacteria in lignin degradation and bio-product formation. Curr. Opin. Biotechnol. 2011, 22, 394-400. [CrossRef] [PubMed]

46. Richards, S.; Gibbs, R.; Weinstock, G. The genome of the model beetle and pest Tribolium castaneum. Nature 2008, 452, 949-955. [CrossRef] [PubMed] 
47. Hou, T.S.; Chiang-Ni, C.; Teng, S.H. Current status of MALDI-TOF mass spectrometry in clinical microbiology. J. Food Drug Anal. 2019, 27, 404-414. [CrossRef] [PubMed]

48. Santos, I.C.; Martin, M.S.; Carlton, D.D., Jr.; Amorim, C.L.; Castro, P.M.L.; Hildenbrand, Z.L.; Zacariah, L. MALDI-TOF/MS for the identification of cultivable organic-degrading bacteria in contaminated groundwater near unconventional natural gas extraction sites. Microorganisms 2017, 5, 47. [CrossRef] [PubMed]

49. Wahl, K.L.; Wunschel, S.C.; Jarman, K.H.; Valentine, N.B.; Petersen, C.E.; Kingsley, M.T.; Zartolas, K.A.; Saenz, A.J. Analysis of microbial mixtures by matrix-assisted laser desorption/ionization time-of-flight mass spectrometry. Anal. Chem. 2002, 74, 6191-6199. [CrossRef] [PubMed]

50. Vasquez, A.; Forsgren, E.; Fries, I.; Paxton, R.J.; Flaberg, E.; Szekely, L.; Olofsson, T.C. Symbionts as major modulators of insect health: Lactic acid bacteria and honeybees. PLoS ONE 2012, 7, e33188. [CrossRef]

51. Shao, Y.; Arias-Cordero, E.; Guo, H.; Bartram, S.; Boland, W. In vivo Pyro-SIP assessing active gut microbiota of the cotton leafworm, Spodoptera littoralis. PLoS ONE 2014, 9, e85948. [CrossRef]

52. Ruiz-Rodriguez, M.; Valdivia, E.; Martin-Vivaldi, M.; Martin-Platero, A.M.; Martinez-Bueno, M.; Mendez, M.; Peralta-Sánchez, J.M.; Soler, J.J. Antimicrobial activity and genetic profile of enteroccoci isolated from hoopoes uropygial gland. PLoS ONE 2012, 7, e41843. [CrossRef]

53. Pittman, G.W.; Brumbley, S.M.; Allsopp, P.G.; O’Neill, S.L. Assessment of gut bacteria for a paratransgenic approach to control Dermolepidaalbohirtum larvae. Appl. Environ. Microbiol. 2008, 74, 4036-4043. [CrossRef]

54. Schloss, P.D.; Delalibera, I.; Handelsman, J.; Raffa, K.F. Bacteria associated with the guts of two wood-boring beetles: Anoplophora glabripennis and Saperda vestita (Cerambycidae). Environ. Entomol. 2006, 35, 625-629. [CrossRef]

55. Dantur, K.I.; Enrique, R.; Welin, B.; Castagnaro, A.P. Isolation of cellulolytic bacteria from the intestine of Diatraea saccharalis larvae and evaluation of their capacity to degrade sugarcane biomass. AMB Express 2015, 5, 15. [CrossRef] [PubMed]

56. $\mathrm{Hu}, \mathrm{X} . ; \mathrm{Yu}, \mathrm{J} . ;$ Wang, C.; Chen, H. Cellulolytic bacteria associated with the gut of Dendroctonusarmandilarvae (Coleoptera: Curculionidae: Scolytinae). Forests 2014, 5, 455-465. [CrossRef]

57. Huang, S.; Sheng, P.; Zhang, H. Isolation and identification of cellulolytic bacteria from the gut of Holotrichia parallela larvae (Coleoptera: Scarabaeidae). Int. J. Mol. Sci. 2012, 13, 2563. [CrossRef] [PubMed]

58. Pawar, K.D.; Dar, M.A.; Rajput, B.P.; Kulkarni, G.J. Enrichment and identification of cellulolytic bacteria from the gastrointestinal tract of giant African snail, Achatina fulica. Appl. Biochem. Biotechnol. 2015, 175, 1971-1980. [CrossRef] [PubMed]

59. Dillon, R.J.; Dillon, V.M. The gut bacteria of insects: Nonpathogenic interactions. Annu. Rev. Entomol. 2004, 49, 71-92. [CrossRef] [PubMed]

60. Suen, G.; Scott, J.J.; Aylward, F.O.; Adams, S.M.; Tringe, S.G.; Pinto-Tomas, A.A.; Foster, C.E.; Pauly, M.; Weimer, P.J.; Barry, K.W.; et al. An insect herbivore microbiome with high plant biomass-degrading capacity. PLoS Genet. 2010, 6, e1001129. [CrossRef]

61. Okeke, B.C.; Lu, J. Characterization of a defined cellulolytic and xylanolytic bacterial consortium for bioprocessing of cellulose and hemicelluloses. Appl. Biochem. Biotechnol. 2011, 163, 869-881. [CrossRef]

62. Ko, K.C.; Han, Y.C.; Hyun, K.J.; Geun-Joong, L.; Seung-Goo, S.J.J. A novel bifunctional endo-/exo-type cellulase from an anaerobic ruminal bacterium. Appl. Microbiol. Biotechnol. 2011, 89, 1453-1462. [CrossRef]

63. Sreeja, S.J.; Jeba-Malar, P.W.; Sharmila-Joseph, F.R.; Tiburcius, S.; Immanuel, G.; Palavesam, A. Optimization of cellulase production by Bacillus altitudinis APS MSU and Bacillus licheniformis APS2 MSU, gut isolates of fish Etroplus suratensis. Int. J. Adv. Res. Technol. 2013, 2, 401-406.

64. Shivaji, S.; Chaturvedi, P.; Suresh, K.; Reddy, G.S.N.; Dutt, C.B.S.; Wainwright, M.; Narlikar, J.V.; Bhargava, P.M. Bacillus aerius sp. nov., Bacillus aerophilus sp. nov., Bacillus stratosphericus sp. nov. and Bacillus altitudinis sp. nov., isolated from cryogenic tubes used for collecting air samples from high altitudes. Int. J. Syst. Evol. Microbiol. 2006, 56, 1465-1473. [CrossRef]

65. Mao, S.; Lu, Z.; Zhang, C.; Lu, F.; Bie, X. Purification, characterization, and heterologous expression of a thermostable $\beta-1,3-1,4-$ glucanase from Bacillus altitudinis YC-9. Appl. Biochem. Biotechnol. 2013, 169, 960-975. [CrossRef]

66. Vettath, V.K.; Junqueira, A.C.M.; Uchida, A.; Purbojati, R.W.; Houghton, J.N.I.; Chénard, C.; Drautz-Moses, D.I.; Wong, A.; Kolundžija, S.; Clare, M.E.; et al. Complete genome sequence of Bacillus altitudinis type strain SGAir0031 isolated from tropical air collected in Singapore. Genome Announc. 2017, 5, e01260-17. [CrossRef]

67. Sadaqat, B.; Sha, C.; Rupani, P.F.; Wang, H.; Zuo, W.; Shao, W. Man/Cel5B, a bifunctional enzyme having the highest mannanase activity in the hyperthermic environment. Front. Bioeng. Biotechnnol. 2021, 9, 637649. [CrossRef] [PubMed]

68. Shakoor, S.; Saira, A.; Abdul, R. Characterization of cellulose degrading bacterium Bacillus megaterium S3, isolated from indigenous environment. Pak. J. Zool. 2013, 45, 1655-1662.

69. Mathews, S.L.; Epps, M.J.; Blackburn, R.K.; Goshe, M.B.; Grunden, A.M.; Dunn, R.R. Public questions spur the discovery of new bacterial species associated with lignin bioconversion of industrial waste. R. Soc. Open Sci. 2019, 6, 180748. [CrossRef] [PubMed]

70. Sharma, A.; Parashar, D.; Satyanarayana, T. Acidophilic microbes: Biology and applications. In Biotechnology of Extremophiles, Grand Challenges in Biology and Biotechnology; Rampelotto, P.H., Ed.; Springer: Cham, Switzerland, 2016; pp. 215-241. [CrossRef]

71. Sun, X.; Liu, Z.; Qu, Y.; Li, X. The effects of wheat bran composition on the production of biomass-hydrolyzing enzymes by Penicillium decumbens. Appl. Biochem. Biotechnol. 2008, 146, 119-128. [CrossRef]

72. Ma, L.; Lu, Y.; Yan, H.; Wang, X.; Yi, Y.; Shan, Y.; Liu, B.; Zhou, Y.; Lu, X. Screening of cellulolytic bacteria from rotten wood of Qinling (China) for biomass degradation and cloning of cellulases from Bacillus methylotrophicus. BMC Biotechnol. $2020,20,2$. [CrossRef] 
73. Gomare, S.; Kim, H.A.; Ha, J.H.; Lee, M.W.; Park, J.M. Isolation of the polysaccharidase producing bacteria from the gut of sea snail, Batillus cornutus. Korean J. Chem. Eng. 2011, 28, 1252-1259. [CrossRef]

74. Cho, M.J.; Kim, H.Y.; Shin, K.; Kim, Y.K.; Kim, Y.S.; Kim, T.J. Symbiotic adaptation of bacteria in the gut of Reticulitermes speratus: Low endo-b-1, 4-glucanase activity. Biochem. Biophys. Res. Commun. 2010, 395, 432-435. [CrossRef]

75. Ferbiyanto, A.; Rusmana, I.; Raffiudin, R. Characterization and identification of cellulolytic bacteria from gut of worker Macrotermes gilvus. Hayati J. Biosci. 2015, 22, 197-200. [CrossRef]

76. Islam, F.; Roy, N. Screening, purification and characterization of cellulase from cellulase producing bacteria in molasses. BMC Res. Notes 2018, 11, 445. [CrossRef] [PubMed]

77. Manfredi, A.P.; Perotti, N.I.; Martínez, M.A. Cellulose degrading bacteria isolated from industrial samples and the gut of native insects from Northwest of Argentina. J. Basic Microbiol. 2015, 55, 1384-1393. [CrossRef] [PubMed]

78. Li, H.; Wu, S.; Wirth, S.; Hao, Y.; Wang, W.; Zou, H.; Li, W.; Wang, G. Diversity and activity of cellulolytic bacteria, isolated from the gut contents of grass carp (Ctenopharyngodon idellus) (Valenciennes) fed on Sudan grass (Sorghum sudanense) or artificial feedstuffs. Aquac. Res. 2014, 47, 153-164. [CrossRef]

79. Júnior, F.L.S.; Dias, A.C.F.; Fasanella, C.C.; Taketani, R.G.; Lima, A.O.; Melo, I.S.; Andreote, F.D. Endo-and exoglucanase activities in bacteria from mangrove sediment. Braz. J. Microbiol. 2013, 44, 969-976. [CrossRef] [PubMed]

80. Yang, W.; Meng, F.; Peng, J.; Han, P.; Fang, F.; Ma, L.; Cao, B. Isolation and identification of a cellulolytic bacterium from the Tibetan pig's intestine and investigation of its cellulase production. Electron. J. Biotechnol. 2014, 17, 262-267. [CrossRef]

81. Singh, S.; Moholkar, V.S.; Goyal, A. Isolation, identification, and characterization of a cellulolytic Bacillus amyloliquefaciens strain SS35 from rhinoceros dung. ISRN Microbiol. 2013, 2013, 728134. [CrossRef]

82. Immanuel, G.; Dhanusha, R.; Prema, P.; Palavesam, A. Effect of different growth parameters on endoglucanase enzyme activity by bacteria isolated from coir retting effluents of estuarine environment. Int. J. Environ. Sci. Technol. 2006, 3, 25-34. [CrossRef]

83. Maki, M.L.; Idrees, A.; Leung, K.T.; Qin, W. Newly isolated and characterized bacteria with great application potential for decomposition of lignocellulosic biomass. J. Mol. Microbiol. Biotechnol. 2012, 22, 156-166. [CrossRef]

84. Barton-Pudlik, J.; Czaja, K.; Grzymek, M.; Lipok, J. Evaluation of wood-polyethylene composites biodegradability caused by filamentous fungi. Int. Biodeterior. Biodegrad. 2017, 118, 10-18. [CrossRef]

85. Xu, K.; Feng, J.; Zhong, T.; Zheng, Z.; Chen, T. Effects of volatile chemical components of wood species on mould growth susceptibility and termite attack resistance of wood plastic composites. Int. Biodeterior. Biodegrad. 2015, 100, 106-115. [CrossRef]

86. Wi, S.G.; Cho, E.J.; Lee, D.S.; Lee, S.J.; Lee, Y.J.; Bae, H.J. Lignocellulose conversion for biofuel: A new pretreatment greatly improves downstream biocatalytic hydrolysis of various lignocellulosic materials. Biotechnol. Biofuels 2015, 8, 228. [CrossRef]

87. Campos, A.; Marconato, J.C.; Martins-Franchetti, S.M. Biodegradation of blend films PVA/PVC, PVA/PCL in soil and soil with landfill leachate. Braz. Arch. Biol. Technol. 2011, 54, 1367-1378. [CrossRef]

88. Schwarz, W.H. The cellulosome and cellulose degradation by anaerobic bacteria. Appl. Microbiol. Biotechnol. 2001, 56, 634-649. [CrossRef]

89. Lu, W.J.; Wang, H.T.; Yang, S.J. Isolation and characterization of mesophilic cellulose-degrading bacteria from flower stalksvegetable waste co-composting system. J. Gen. Appl. Microbiol. 2005, 51, 353-360. [CrossRef] [PubMed]

90. Onipe, O.O.; Afam, I.O. Jideani Beswa, D. Composition and functionality of wheat bran and its application in some cereal food products. Int. J. Food Sci. Technol. 2015, 50, 2509-2518. [CrossRef]

91. Bledzki, A.K.; Mamun, A.A.; Volk, J. Physical, chemical and surface properties of wheat husk, rye husk and soft wood and their polypropylene composites. Compos. Part A Appl. Sci. Manuf. 2010, 41, 480-488. [CrossRef]

92. Fatimah, S.; Sulaiman, M.R.; Hashim, O.; Arai, R.; Kosugi, T.; Abe, A.; Murata, H.Y.; Mori, Y. Characterization of parenchyma and vascular bundle of oil palm trunk as function of storage time. Lignocellulose 2012, 1, 33-44.

93. Kacurakova, M.; Smith, A.C.; Gidley, M.J.; Wilson, R.H. Molecular interactions in bacterial cellulose composites studied by 1D FT-IR and dynamic 2D FT-IR spectroscopy. Carbohydr. Res. 2002, 337, 1145-1153. [CrossRef]

94. Fackler, K.; Stevanic, J.S.; Ters, T.; Hinterstoisser, B.; Schwanninger, M.; Salmén, L. FTIR imaging microscopy to localize and characterize simultaneous and selective white rot decay within spruce wood cells. Holzforschung 2011, 65, 411-420. [CrossRef]

95. Lionetto, F.; Sole, R.D.; Cannoletta, D.; Vasapollo, G.; Maffezzoli, A. Monitoring wood degradation during weathering by cellulose crystallinity. Materials 2012, 5, 1910. [CrossRef]

96. Pandey, K.K. Study of the effect of photo-irradiation on the surface chemistry of wood. Polym. Degrad. Stab. 2005, 90, 9-20. [CrossRef]

97. Wang, L.; Han, G. Yuanming Zhang Comparative study of composition, structure and properties of Apocynum venetum fibers under different pretreatments. Carbohydr. Polym. 2007, 69, 391-397. [CrossRef]

98. Colom, X.; Carrillo, F. Crystallinity changes in lyocell and viscose-type fibers by caustic treatment. Eur. Polym. J. 2002, 38, 2225-2230. [CrossRef]

99. Binod, P.; Satyanagalakshmi, K.; Sindhu, R.; Janu, K.U.; Sukumaran, R.K.; Pandey, A. Short duration microwave assisted pretreatment enhances the enzymatic saccharification and fermentable sugar yield from sugarcane bagasse. Renew. Energy 2012, 37, 109-116. [CrossRef]

100. Kar, K.; Cheng, W. Using Mass Spectrometry to Detect Ethanol and Acetaldehyde Emissions from a Direct Injection Spark Ignition Engine Operating on Ethanol/Gasoline Blends; 2011-1-11959; SAE International in United States: Warrendale, PA, USA, 2011 ; pp. 1-14. [CrossRef] 
101. Sun, Z.; Liu, K.; Zhang, J.; Zhang, Y.; Xu, K.; Yu, D.; Wang, J.; Hu, L.; Chen, L.; Li, C. IAA producing Bacillus altitudinis alleviates iron stress in Triticum aestivum L. seedling by both bioleaching of iron and up-regulation of genes encoding ferritins. Plant Soil 2017, 419, 1-11. [CrossRef]

102. Harish, K.; Reddy, Y.; Srijana, M.; Reddy, D.M.; Reddy, G. Coculture fermentation of banana agro-waste to ethanol by cellulolytic thermophilic Clostridium thermocellum CT2. Afr. J. Biotechnol. 2010, 9, 1926-1934. [CrossRef]

103. Qian, M.; Tian, S.; Li, X.; Zhang, J.; Pan, Y.; Yang, X. Ethanol production from dilute-acid softwood hydrolysate by co-culture. Appl. Biochem. Biotechnol. 2006, 134, 273-283. [CrossRef] 